\title{
NOTE
}

\section{POLITICS AND DUE PROCESS: THE RHETORIC OF SOCIAL SECURITY DISABILITY LAW}

\begin{abstract}
"The history of liberty has largely been the history of observance of procedural safeguards."
\end{abstract}

-Felix Frankfurter ${ }^{1}$

"General propositions do not decide concrete cases."

-Oliver Wendell Holmes ${ }^{2}$

\section{Introduction: Social Security Disability as a Case Study}

In Santosky v. Kramer, ${ }^{3}$ the United States Suprenie Court held that "retrospective case-by-case review cannot preserve fundamental fairness when a class of proceedings is governed by constitutionally defective ... standards." 4 The question remains open, however, as to what a court can and should do instead of case-by-case review. Courts have little power to recast imstitutions: They lack the power of the purse, and they cannot execute laws. In the inodern administrative state, courts often find themselves called upon to address the constitutional adequacy of a class of administrative proceedings. ${ }^{5}$ One example is the proceedings utilized to determine who shall receive Social Security disability benefits. In fulfilling this role in the administrative state, the judiciary confronts a dilemma: Judges nuust ensure the constitutional adequacy of procedures, but they are often impotent to effect structural changes in the substantive mission of bureaucratic institutions.

In responding to this dilemma, judges have tended to act in one of two extremes. They either have limited themselves to retrospective caseby-case review or they have tinkered with bureaucratic procedures. ${ }^{6}$ Retrospective case-by-case review proves inadequate in preserving funda-

1. McNabb v. United States, 328 U.S. 332, 347 (1943).

2. Lochner v. New York, 198 U.S. 45, 76 (1904) (Holmes, J., dissenting).

3. 455 U.S. 745 (1982).

4. Id. at 757.

5. G. Gunther, Constitutional Law 566 (11th ed. 1985). A LEXIS search of the GENFED hibrary, COURTS file, within the years 1970-1990 and with the query "due process" and "agency" found 16,827 cases.

6. See generally D. Horowtrz, The CourTs AND Social Policy 1-23 (1977) (arguing that court tinkerings with administrative and legislative programs have been misconceived). 
Inental fairness when the proceedings under scrutiny are infected with constitutionally flawed standards, and such review offers nothing to those who are unable to bring their case to the courts. Moreover, a particularized review sends a inessage-both to those inside the agency and to the world at large-that only what happened in this particular case, and not the procedure or the substantive mission of the agency generally, is defective. This type of review, therefore, legitimizes the unfair agency process. Tinkering with bureaucratic procedures and agency policy, on the other hand, involves the courts in areas that, under our Constitution, are viewed as inore legitimately the province of the elected Legislative and Executive branches and may be simply beyond the technical competence of judges. Moreover, because judges lack the resources and power-including the power of the purse-necessary to meaningfully alter the structure and scope of agency activity, judicial tinkering simply cannot change the nature of a class of administrative proceedings. As a result, judicial efforts to ainehorate unfair agency proceedings often are ineffectual at best. ${ }^{7}$

Courts have a third option with which to confront the dilemma of ensuring the constitutional adequacy of proceedings, even though they have hittle power to change the substance underlying the proceedings. This Note argues that judges should neither acquiesce and accept the legitimacy of flawed proceedings nor einbroil theinselves in day-to-day agency operations. Instead, judges should use their office to promote a national dialogue that would help create a consistent community vision of what due process and justice mean.

The structure of the American governmental systein linits what judges can effectively do to create inajor shifts in national policy. As a practical matter, a judge often can only effect changes in procedure upon governmental activities that are unfair in their substance. Judges should not, however, put an miplicit stamp of constitutional approval upon governmental activities by remaining silent in the face of unfairness in the structure and scope of agency activity simply because they lack the power to bring about change directly. The power to speak, and moreover, the power to inake oneself heard, is highly significant. Judges shonld inake greater use of this forin of power.

Some bureaucracies are built upon a flawed foundation. No matter how a judge adjusts the process that the bureaucracy uses to make institutional decisions, the structure and mission of the agency will remain flawed. The Social Security disability program ${ }^{8}$ provides an example of

7. See infra notes $89-129$ and accompanying text.

8. Disabled people may qualify for two types of entitlements under the Social Security Actthe Social Security Disability Insurance (SSDI) program and the Supplemental Security Income 
such a flawed institution. This Note examines the disability program as a case study of due process under a system of bureaucratic justice. In three respects the Social Security disability system provides a suitable model for the exploration of due process. First, the central concern of this Note is human dignity values and how they are affected by administrative procedures.9 "Human dignity values" is a mushy and indeterminate phrase. By this phrase, I appeal to the culturally contingent, intuitive sense of natural rights and collective sensibility that helps us make all value judgments. The administrative procedures of government programs only have legitimacy if they comport with human dignity values. This ineans that when the legal process defines the participants and regulates participation, that process must do more than justify the rationality of its substantive results: It must ensure that the participants' sense of personal autonomy and dignity are not violated in a Kafkaesque mightmare. ${ }^{10}$

Second, Social Security disability provides a useful case study because the disability system is a massive part of the apparatus of the nodern welfare state that touches the lives of inost working people. It provides the paradigniatic example of our increasmgly prevalent system

(SSI) program. Eligibility for SSDI benefits does not depend on financial need. See 42 U.S.C. § 423 (1988). SSI provides benefits to disabled individuals who have not participated significantly in the nation's work force as measured by the amount each has paid into the Social Security fund. Eligibility for SSI is dependent upon financial need. Id. $\$ 1382$. Because this difference between SSDI and SSI does not affect the adjudicative procedures applied to participants in the two programs, this Note will use the term "disability program" to refer to both SSDI and SSI when discussing such procedures.

9. This Note is not concerned with the process due corporations. The fifth and fourteenth amendments require that no person shall be deprived of "life, liberty, or property, without due process of law." U.S. CONST. amends. V \& XIV. Only a person divoreed from human feeling and natural logic, as many lawyers and judges regrettably are, could come up with a term like natural persons to describe people, so as to "logically" create our counterpart-the artificial person, or corporation.

Interestingly, the only member of the Court to adopt the view that corporations, as creatures of the states, do not have the constitutional rights of human citizens is Chief Justice Rehnquist. See First Nat'1 Bank v. Bellotti, 435 U.S. 765, 824 (1978) (Relnquist, J., dissenting) ("mere creation of a corporation does not invest it with all the liberties enjoyed by natural persons").

The Supreme Court first held a corporation to be a person under the fourteenth amendment in Santa Clara Co. v. Southern Pac. R.R., 118 U.S. 394 (1886). Although now almost axiomatic, the decision was controversial at the time, and became one of the prominent symbols to the progressive constitutional historians demonstrating the subservience of the Supreme Court to the interests of big business. See Horwitz, Santa Clara Revisited: The Development of Corporate Theory, 88 W. VA. L. Rev. 173, 173-74 (1985).

10. See F. KafKa, The Trial (1925); F. KafKa, The Castle (1926). In The Trial, the hero is accused of an unnamed crime, of which he knows nothing. The novel concerns an individual's many fruitless attempts to obtain justice from an authority with which he cannot even effectively cominunicate, and culminates in his utter frustration, death, and his complete loss of human dignity. In The Castle, the hero, a land surveyor, is frustrated in his efforts to gain entrance to a mysterious castle, whicl is administered by an extraordinarily complicated and inaccessible bureaucratic hierarchy. 
of mass justice. ${ }^{11}$ Approximately 1.2 million imitial claims for disability benefits are processed annually under the Social Security Act. ${ }^{12}$ In addition, many of these claims go through several reviews before the decision is final. In 1988, claimants appealed 438,251 initial-stage denials for a reconsideration decision. ${ }^{13}$ Demals at the reconsideration stage prompted 258,421 requests for hearings before administrative law judges (ALJs). ${ }^{14}$ Of these hearing cases, 57,193 went on to a final administrative appeal before the Social Security Appeals Council, ${ }^{15}$ and claimants made 11,412 filings for judicial review of Social Security disability decisions in the federal district courts. ${ }^{16}$

At each stage, a case may be remanded to a lower level for reconsideration. Moreover, under the Continuing Disability Review (CDR) program, over 318,000 existing beneficiaries had their status reviewed and reconsidered in a similar process. ${ }^{17}$ There are approximately 5,600 state agency personnel (supported by some 5,000 more) whose sole function is to adjudicate disability claims, ${ }^{18}$ and more than 700 federal ALJs hear administrative appeals from state agency demials. ${ }^{19}$ This total of more than 6,000 adjudicators approaches the size of the judicial systems of the fifty states and of the federal government combined. ${ }^{20}$ Furthermore, over four million disabled workers and their families depend on these benefits. ${ }^{21}$

11. See J. Mashaw, Bureaucratic Justice 18 (1983).

12. U.S. Dep't of HeAlth and Human SERvs., Social SEC. Admin., 1989 ANNuAl RePORT TO THE CONGRESS 29 (1989) [hereinafter 1989 SSA ANNUAL REPORT].

13. Staff of the House Comm. on Ways and Means, 101st Cong., 1st Sess., Background Material and Data on Programs within the Jurisdiction of the CommitTeE on Ways and Means 51 (table 4) (Comm. Print 1989) [hereinafter Ways and Means Green BOOK].

14. Id.

15. Id.

16. Administrative Office of the U.S. Courts, 1989 annual Report of the DirecTOR app. 1, at 23 (1989) [hereinafter 1989 ADMINISTRATIVE OfFice ANNUAL REPORT] (table of "Civil Cases Commenced, By Basis of Jurisdiction").

17. WAYS AND MEANS GREEN Book, supra note 13, at 51 (table 4).

18. J. MASHAW, supra note 11, at 18.

19. 1989 SSA ANNUAL REPORT, supra note 12, at 16. This represents about $70 \%$ of the ALJ's in the federal government. Id.

20. J. MASHAW, supra note 11 , at 18 .

21. WAyS AND MEANS GREEN Boox, supra note 13, at 56 . In fiscal year 1984, benefits amounted to $\$ 21.3$ billion. 1989 SSA ANNUAL REPORT, supra note 12, at 29. The 1989 estimate is $\$ 22.3$ billion. Id. When Medicaid and Medicare payments, which beneficiaries are automatically eligible for (although SSDI beneficiaries must wait two years after their disability award before they receive Medicare coverage), are included, the total figure rises above $\$ 42$ billion. Determined by addition based upon the following: Division of Medicald STATISTICS, OfFice of STatistics aNd Data MANagement, ANNuAl StatistiCal Report ON MEDicaid (1988) (Form HCFA2082); DIVISION OF MEDICARE INFormation ANALYSIS, OFFICE OF STATISTICS AND Data MANAGEMENT, HCFA DATA COMPENDiUM FisCAL YeAR 1990, at 27 (1989). 
Finally, the Social Security disability system provides useful material for the exploration of due process in the context of inass administrative justice because the levels of the decisional process at which most of the cases are decided-the initial and reconsideration stages of the state agency process-are virtually invisible to those outside the system. ${ }^{22}$ This invisibility is a central factor in the failure of retrospective case-bycase review to preserve fundamental fairness. One cannot conclude that those who get to court are merely the few for whom the safety net failed. Substantial structural barriers block unsuccessful claimants from reaching the district courts. Considerable stamina is required just to fill out the necessary paper work. Indeed, less than half of the nearly one milhon applicants who are denied benefits based upon their initial application make the effort to apply for even the first level of state administrative reconsideration-which is three levels of review below the district court. ${ }^{23}$ It takes years for a case to reach the district courts, and lawyer's fces are limited to twenty-five percent of past due benefits received, if any. ${ }^{24}$ Most disability applicants are older, poorly educated, with few resources, and by definition in poor health. ${ }^{25}$ Only the exceptional and relatively well-off clannant has the wherewithal and the knowledge to fight the Social Security bureaucracy.

The federal courts largely have resisted pressures to make structural changes in Social Security procedures or to alter or recast the substantive mission of the agency. Rarely is an administrative procedure called into question in a general sense, and the gaps and flaws in the structure and mission of the agency are almost never reviewed. ${ }^{26}$ To be sure, administrative law's incantations and "magic words" appear and reappear throughout the case law-"notice," the opporturity to be heard at a "meaningful time" and in a "meaningful manner," etc. But these words

22. See infra notes $55-70$ and accompanying text. Of the 985,801 disability decisions rendered by state agencies in 1981 , only 7,293 cases were decided by the federal courts. STAFF of SENATE Comm. on Finance, 97Th CONg., 2D Sess., Data and Materials Related to the Social Security Disability Insurance Program 93 (Comm. Print 1982) [hereinafter SSDI Data AND MATERIALS].

23. See WAYS AND MEANS GREen Book, supra note 13, at 51.

24. 42 U.S.C. $\$ 406$ (a) (1988). Although we may not want the claimant's or the SSA's money eaten up by lawyer's fees, the limited funds available for fees do not make this practice attractive to the best legal talent. Moreover, a perverse incentive is created for the lawyer to delay the award as long as possible to raise the size of the retroactive benefit received.

25. See infra notes $41-48$ and accompanying text.

26. Of the relatively few claims that reach the federal courts, most are disposed of on the evidentiary question of whether or not the agency decision was supported by substantial evidence, and thus have hittle precedential value. See H.R. REP. No. 618, 98th Cong., 2d Sess. 23, reprinted in 1984 U.S. CODE CONG. \& ADMIN. News 3038, 3060. 
are hollow, malleable to whatever the judge chooses to sanction im a particular case. ${ }^{27}$

By limiting themselves to case-by-case review, and by deciding cases with the supposedly neutral "magic words" of due process analysis, courts grant legal approval to agency action and hence buttress the legitimacy of an unfair class of proceedings. Even if the courts do not, as a practical matter, have much power to effect substantive change within the context of a single case, judges must stop putting a veneer of inevitability and legitimacy on administrative procedures. This Note asserts that although the structure and pohtics of American government limits the scope of judicial power, courts nevertheless should articulate the nature of their institutional limitations. Courts then should express the insights and opinions (im the conventional sense) that their unique perspective has given them on the system and its procedures, in order to assist, educate, and influence the other branches of the government and the public in creating a more democratically meaningful constitutional discourse. Even though this articulation of values begins with writing opinions in a more accessible style, judges should not restrict themselves to acting ex cathedra. Judges also should organize and speak out pubhicly to make the law accessible and understandable to the American people and to influence policyinakers and administrators, who can transform our institutions into a form more consistent with the popular, democratic vision of fairness that the Constitution mandates. If judges saw theinselves as political actors in the role of articulators of social vision, rather than as technicians, then the promise of a democratic Constitution would be better fulfilled.

To explore what judges can and should do, this Note examines the Social Security disability system. Part I describes the incomplete congressional definition of disability and how this definition operates withni the disability determination process. This Part also explores the determination process, which has detailed guidelines, procedures, and inanagement oversight. But what appears coherent and primcipled to managers and lawyers often seems arbitrary and unfair from the claimant's perspective. Part II examines the question of what process is due. This Part criticizes the currently dominant rhetoric of due process-a rhetoric that ignores the need for governmental determinations to account for their impact on the dignity of those affected.

Part III explains how substantial pragniatic, structural, and ideolog. ical restraints prevent or dissuade judges froin attempting much inore than case-by-case review. This Part examines why procedural interven-

27. See infra notes 130-83 and accompanying text. 
tion in unfair agency procedures often has done little for those it was meant to help. Part III then argues that the professional norms that currently restrain judges froin speaking out to influence social and political values are pernicious and ahistorical. The insular norms of the legal profession that currently control judicial behavior sliould be supplanted with pohitically determined dernocratic standards. Part IV concludes that although the role of judges in the American pohitical system is limited, their inandate as the interpreters of the Constitution requires that they actively participate in a democratic, social quest to discover and create constitutional meaning.

\section{The Enabling legislation and the Regulations: A Case STUDY IN CONTRADICTION AND AMBIGUITY}

\section{A. Born of Compromise, Created in Confusion}

The congressional choices with regard to who does and does not receive support from the disability program make little sense and leave large gaps in the social safety net. For a person to be found disabled, he inust be unable to work by reason of his medical condition at any type of job that "exists in the national economy, regardless of whether such work exists in the immediate area in which lie lives, or whether a specific job vacancy exists for him, or whether lie would be hired if he applied for work." 28 Thus, a worker who, despite health probleins, has the physical and mental ability to do soine job that exists soinewhere in tlie national econoiny is not disabled. Employers, however, have access to a pool of healthy workers from which they will prefer to hire. This leaves the claimant witl little chance of finding a job. ${ }^{29}$

Theoretically, soine kind of work could be found or created for everyone, regardless of age, disability, or ability. Virtually everyone is capable of doing something productive. However, disability or unemployment benefits are not determined by asking wliether the person can work. Ratlier, the programs ask whetlier the claimant's reasons for not working are wortliy of benefits-that is, whether the reasons are deemed a socially acceptable excuse.

At bottoin, all unemployment turns on the imtersection of a complex matrix of factors that include an individual's abilities, including lier physical abilities, and the exigencies of a market economy. Thus, unem-

28. 42 U.S.C. $\S 423(d)(2)$ (A) (1988).

29. J. MASHAW, supra note 11, at 52. The laws of supply and demand dictate that in a relatively tight labor market employers will be more likely to hire less productive ailing workers than in a period when there are many fully able-bodied workers seeking employment. It is thus reasonable to assume that many, if not most, claimants will be unable to find employment. 
ployability and disability are not discrete categories; instead, they are points along a continuum. ${ }^{30}$ Yet under the disability program there are no gradations of disability. Either a claimant qualifies as totally disabled or she does not. This bimary form of disability determination is incoherent given individual variations and the complexities of the market. Further, payinent amounts are not related to the degree of disability or, in the case of the Title II program, to need. ${ }^{31}$ Benefits are statutorily prescribed to equal retirement or survivors' benefits. ${ }^{32}$ Disability seems in many ways to be merely a socially approved form of early retirement.

The inconsistent criteria that the Social Security Administration (SSA) is instructed to einploy in making disability classifications further demonstrates Congress' muddled intent. First, the Social Security Act requires that disability be assessed without regard to the likelihood of the

30. Unemployment and disability are linked, but Congress has kept them separate for reasons that are not entirely clear. Perhaps the reason relates to the experience of private disability insurance during the Depression. Many insurers were bankrupted by judicial expansion of their policies' conception of covered risk; all private carriers abandoned the field when judicial construction, in the face of rising unemployment, made disability actuarially unpredictable. The potential liability in times of high unemployment of a system that links employability and disability is, of course, enormous. See M. Derthick, Pol.1cymaking for Social Security 299 (1979); J. Mashaw, supra note 11, at 34; see also RePort of THE ADVISORY COUNCIL ON SOCIAL SECURITY TO THE SENATE Committee on Finance, S. Doc. No. 208, 80th Cong., 2d Sess. 80.92 (1949).

The original Social Security Act of 1935 included no provision for the disabled. Social Security Act of 1935, ch. 531, tit. I, 49 Stat. 620 (codified as amended at 42 U.S.C. $\S \S 301-1397(f)$ (1988)). It has been suggested that the omission of any disability insurance program resulted froin the congressional conclusion that disability insurance is the most difficult of all forms of social insurance and therefore should be considered as one of the items to come last in a coinplete program for economic security. R. DIXoN, SOCIAl SECURITY AND MASS JUSTICE 14 (1973).

The SSDI program was enacted in 1956. Amendments to Title II of the Social Security Act, ch. 836, tit. I, $\S 103,70$ Stat. 815 (1956) (codified as amended at 42 U.S.C. $\S 423$ (1988)). The mitial legislation was quite limited, covering only about 150,000 disabled Americans, and costing ouly about $\$ 59$ million. Weinstein, Equality and the Law: Social Security Disability Cases in the Federal Courts, 35 SYRAcuSE L. REv. 897, 904 (1984) (citing S. REP. No. 648, 97th Cong, 2d Sess. 2 (1982), reprinted in 1982 U.S. CODE CONG. \& ADMIN. NEWs 4373, 4387; SSDI DATA AND MATERIAIS, supra note 22, at 7, 19, 20).

The SSI program to provide benefits for disabled individuals on a needs basis was created in 1972. Social Security Amendments of 1972, Pub. L. No. 92-603, 86 Stat. 1329 (codified as amended at 42 U.S.C. $\S \S 1381-83$ (1988)); see 20 C.F.R. $\S \S 416.1100$ - 1266 (1989) (setting forth economic ehigibility guidelines for Supplemental Security Income (SSI) benefits).

31. The Title II program, like Social Security retirement benefits, is an entitlement program. The benefits are the same as would be paid upon retirement. See 42 U.S.C. $\S 423$ (1988); see also supra note 8. The Title XVI program is essentially a welfare program. Under Title XVI, a needy person (defined as having less than specified amounts of incoine and assets) who is disabled qualiftes for Supplemental Security Incone (SSI) benefits. 42 U.S.C. $\S 1382$ (1988). Disability is defined in exactly the same terms as in Title II. See J. Mashaw, C. GoETz, F Goodman, W. Schwartz, P. Verkuil \& M. Carrow, Social Security Hearings and Appeals xv (1978) [hereinafter SoCLAL SECURITY HEARINGS]; see also supra notes 8 \& 30.

32. 42 U.S.C. $\S 423$ (1988); WAYS AND MEANS GREEN BooK, supra note 13, at 41 . In 1988, the average benefit amount for a disabled worker was $\$ 530$ per month. 
claimant ever being hired. ${ }^{33}$ But it also inakes the claimant's age an independently significant variable in the inatrix for determining disability status. ${ }^{34}$ Congress established incoine support for the disabled, not unemployed older workers, and yet it recognized the link between physical condition, age, and employability. Second, the statute requires that the SSA consider the claimant's education and work experience. ${ }^{35} \mathrm{How}-$ ever, if the disability program is designed to deal with long-term or perinanent functional incapacity, then current skill level-as opposed to potential for inastering a new skill-should not be significant.

With respect to the actual inedical impairments, the regulations are hopelessly vague and subjective. ${ }^{36}$ When Congress formulated the legislation, it decided that for budgetary and control reasons, the determinations of a claimant's doctor that the claimant was disabled should not dictate the ultimate outcome of the case. ${ }^{37}$ But the proposal that the SSA should create and run its own diagnostic and treatment centers ran into a political impasse: The American Medical Association fought this by calling forth the specter of "socialized inedicme." 38 As a result, disability is not a medical diagnosis but rather a legal conclusion based on medical facts-a determination inade by bureaucrats who are not medically trained. ${ }^{39}$

It is possible to imagine a system forged in political compromise and reflecting conflicting goals that is fair and efficient in its implementation. Thus, to determine if an agency's operation is, in fact, as confused as the compro1mise embodied in its conception suggests, we 1nust examine the actual workings of the system: How those who must use its services maneuver through its operations, and how its officials inake their subjective, discretionary determinations.

33. See supra notes 29-30 and accompanying text; see also J. MASHAW, supra note 11, at 52-55.

34. 42 U.S.C. $\S 404$ (1988); see also 20 C.F.R. $\$ 404.1599$ app. 2 (1989).

35. 42 U.S.C. $\$ 404$ (1988).

36. See id.; see also infra notes $44-70$ and accompanying text.

37. 1956 U.S. CoDe CoNG. \& ADMIN. NEws 3945-47. See also M. DeRTHICK, supra note 30, at 295-315; J. MASHAw, supra note 11 , at 37.

38. M. DERTHICK, supra note 30 , at 295-314. If there is an apparent contradiction in the fact that the medical and the administrative definitions of "disabled" are unlinked such that doctors cannot make the legal determination of disability and the administrators cannot make the necessary underlying medical determinations, then the answer would he in having people who could do both. In Mathews v. Eldridge, 424 U.S. 319 (1975), the Supreme Court erroneously implied that determining disability from often conflicting medical reports was an objective task. Id. at 337; see infra notes 134-52 and accompanying text.

39. See 20 C.F.R. $§ \S 404.1615-.1622$ (1989). 


\section{B. The Disability Determination Process}

The Social Security disability insurance systein vests substantial discretionary power in low-level officials. Despite this discretion, the decisional processes must operate in a bureaucratically rational inanner that management can oversee in an "objective" way. What is coherent, however, from inanagement's point of view inay seem arbitrary and unfair from both the claimant's and the public's perspective.

An applicant for Social Security disability benefits must maneuver through a inassive, complex systein. The complexity of the system can be attributed to two factors: (1) the incoherent statutory definition of "disability" and the difficulties this creates in benefit-determinations; and (2) the division of labor among a variety of bureaucratic entities including the Bureau of Disability Insurance of the SSA, state vocational and rehabilitation agencies, administrative law judges, the Appeals Council of the SSA, and finally, the federal courts. ${ }^{40}$ These two factors serve to make navigating the systein an unfair burden on many claimants.

The statutory definition of disability requires that a worker demonstrate his "inability to engage in any substantial activity by reason of any medically determinable physical or mental impairment which can be expected . . . to last for a continuous period of not less than 12 inonths ...."41 To satisfy this test, the claimant bears a continuous burden ${ }^{42}$ of showing by ineans of "medically acceptable clinical and laboratory diagnostic tecliniques"43 that his impairment is of such severity that he is unable not only to do his previous work but,

considering his age, education, and work experience, [to] engage in any other kind of substantial gainful work which exists in the national econoiny, regardless of whether such work exists in the immediate area in which he lives or whether a specific job vacancy exists for him, or whether he would be hired if he applied for work. ${ }^{44}$

Because this statutory definition of disability is quite general, certain impairments have been defined by the SSA as per se disabilities. ${ }^{45}$ In approximately one of four cases, however, the effect of medical inpairments on a claimant's functional capacity for einployment must be evalu-

40. See Mashaw, The Supreme Court's Due Process Calculus for Administrative Adjudication in Mathews v. Eldridge: Three Factors in Search of a Theory of Value, 44 U. CH1. L. REV. 28, 31-33 (1976) (arguing that a major reason for unmanageability of Social Security is due to division of labor among four administrative bodies); see also 20 C.F.R. $\$ \S 404.1270-1290$ (1989).

41. 42 U.S.C. $\S 423$ (d)(1)(A) (1988).

42. The burden is continuing because benefits only can be continued as long as the disabling condition persists. Id. $\S 423(\mathrm{f})$.

43. Id. $\$ 423(\mathrm{~d})(3)$.

44. Id. $\S 423(\mathrm{~d})(2)(\mathrm{A})$.

45. 20 C.F.R. $\S 404$ app. 1 , $\$ 404.1520($ a) (1989). 
ated in light of various nonmedical factors. ${ }^{46}$ Thus, decisionmakers often must translate a inedical impairment into functional limitations on a person's physical abilities and then evaluate the effect of those functional limitations on the claimant's capacity to engage in "substantial gainful activity" (that is, work at a job), given his age, education, and work experience. 47 A procedure that begins with medical reports concerning clinical diagnosis and treatment becoines a process of highly subjective judgment, in which the subconscious biases and prejudices of the deciding official may play a significant role in the outcoine. ${ }^{48}$

The SSA's medical-vocational "grids" offer an example of a decisionmaking process that is rational and objective froin manageinent's perspective, but from the claimant's perspective may be arbitrary and subjective. In cases in whicl the claimant's disability neitlier "ineets" nor "equals" the "histings" of per se disabling conditions published by the SSA in the Code of Federal Regulations, ${ }^{49}$ a claims-processor or an ALJ (depending upon the stage of review) makes wliat necessarily is a somewliat subjective determination as to the "residual functional capacity" of the claimant based upon the medical record and, in the case of an ALJ, the liearing..$^{50}$ Prior to 1978 , if the claimant's condition did not fall within one of the categories delineated in tlre medical listings as a per se

46. WAYS AND MEANS GREEN BOoK, supra note 13, at 46 (table 2); "Basis for Title II Allowances-Initial Worker Determinations," id. at 47 (table 3); "Basis for Title II disallowances and Denials-National Figures: Initial Work Determination" id. app. at 2; Mashaw, supra note 40, at 32.

47. The functional capacity judgment requires consideration of at least the following determinants:

(1)the degree to which disease or trauma has produced impairments, that is, abnormalities in the claimant's physical or mental structure; (2) the degree to which these impairments result in activity losses or restrictions, usually characterized as functional limitations; (3) the degree to which the claimant's impairments and functional limitations affect the required capacities for the performance of normal roles and activities, imcluding an analysis of attendant therapeutic limitations, environmental restrictions, energy reserve losses, and psychological overlays; (4) the interaction of the claimant's age, education, and prior work experience with his functional limitations and his response to then, and the effect of this conbination of factors ou his capacity for work available in the national econony.

Mashaw, supra note 40 , at 42 (footnote omitted).

48. Id. at 41. The impact of these biases reveals itself in the fact that different officials will often reach different decisions for the same claimant. See infra notes 61-67 and accompanying text.

49. A claimant's condition neets the listings when it is the same disability as that contained in the listing. A clainuant's condition equals the listing when the condition or conditions produce an impairment equivalent to those coutained in the listing. The determination of whether or not a claimant's condition is "equal" to those contained in the listing may be, of course, a fairly subjective determination. See 20 C.F.R. $\S 404.1526$ (1989).

50. 20 C.F.R. $\S 404$ Subpart $P$ app. at 2 (1989). This judgment must be based upon substantial evidence contained in the record as a whole, but the claimant's treating physician's report is not necessarily given controlling weight. Moreover, a doctor's examination concerns only tangentially a patient's ability to nuanage in work situations. Although a doctor's report in extreme cases may preclude a claimant froin being placed in too difficult a work category, in cases closer to the line the bureaucratic assessment is not open to nedical disprovement. 
disabling condition, then the SSA rehed upon "vocational experts" to make an individual determination as to the existence of jobs in the national economy suitable to the claimant's abilities. After a claimant's limitations and abilities were evaluated at a hearing, the vocational expert would testify as the whether work existed that the plaintiff could perform. In the face of a growing number of noumedical allowances and frequent criticism of the vocational experts' inconsistent treatment of similarly situated claimants, the SSA developed a vocational "grid" system to replace individual determinations. The use of the grids allows the SSA to dispense with vocational experts by establishing through rulemaking a formula to determine the claimant's ability to work based upon the factors described above. ${ }^{51}$ The claims-adjustor or ALJ determines how much the claimant can lift, how many hours the claimant can stand, and other similar factors, and then categorizes the claimant as having the "residual functional capacity" (RFC) to perform the workrelated activities designated as "sedentary," "light," "medium," or "heavy."52

After this determination, the decisioumaker chooses the RFC table that is consistent with the above categorization of the claimant's physical ability. The decisioumaker then selects the appropriate boxes within each of three categories: age, education, and previous work experience. ${ }^{53}$ The SSA rules identify whether jobs that require specific combinations of these factors exist in significant numbers in the national econoiny. If a claimant's categorization corresponds to the job requirements identified by a rule, then the grid table directs a conclusion as to whether work exists that the claimant could perform. ${ }^{54}$ The grid "objectively" determines whether an individual is "disabled" or is simply a "inalingerer."

The Byzantine structure of decisioumaking further complicates this process for the claimant. ${ }^{55}$ First, an applicant applies at a district office of the SSA. At the district office, a claims processor determines, on the basis of the claimant's prior earnings and contributions to the Social Security system, whether she is eligible for Social Security benefits. The

51. Heckler v. Campbell, 461 U.S. 458, 461-62 (1983); WAys AND MEANS GreEN Book, supra note 13, at 45. See also supra notes $42-48$ and accompanying text. In Heckler, the Court upheld the establishment of the medical-vocational guidelines via rulemaking, in place of vocational experts, as neither arbitrary and capricious nor in conflict with the Social Security Act and consistent with due process. Heckler, 461 U.S. at 467-68.

52. 20 C.F.R. $\S 404$ Subpart P app. at 2 (1989).

53. Id.

54. Id. Ability to perform other work was the stated reason for disallowances and denials at the initial stage in 23\% of the cases in 1988. WAYS AND MEANS GREEN BOOK, supra note 13, at 47 (table 3).

55. The sequence of procedures that applies to both the granting of benefits and their termination is described in 20 C.F.R. $\S \S 404.901-.996$ (1989). 
case then is referred to a state agency-usually the state vocational and rehabilitation service-where an adjudication unit assembles medical and vocational evidence and makes an initial decision on the claim. If the state agency demes the claim and the SSA affirms the demal, then the claimant is notified that she is entitled to a de novo reconsideration of her claim by the state agency. If a reconsideration is requested, then the clain 1 is reviewed by a different state agency unit. All of these determinations and reviews are done on paper.

If the claim is demed again, then the clainiant is informed that she is entitled to a de novo hearing before a federal administrative law judge. ${ }^{56}$ The ALJ usually is the first person to decide the case who will see the claimant or hear any oral testimony or argument. ${ }^{57}$ If the claimant loses before the ALJ, she may request a discretionary review by the Appeals Council of the Social Security Administration. ${ }^{58}$ If the Appeals Council disinisses the request or demies the claim on the merits, then the claimant may seek judicial review in a federal district court. ${ }^{59}$

Congress created the social insurance system to respond to the demand of the American people that support be provided to mdividuals who are unable to support themselves for socially acceptable reasons. The current social insurance system-with its bimary decisional algorithm, its Byzantine appeal structure, and the large gaps in its coverage-assesses an individual's reasons for non-participation in the work force im a manner that is at odds with the way inost people would judge the acceptability of those reasons. ${ }^{60}$ Thus, although adherence to rules and a focus on quantifiable bureaucratic goals (rather than on the more ainorphous underlymg social goals) may protect a claimant from some forms of arbitrariness, it also subjects him to a different kind of arbitrariness-bureaucratic decisionmaking that does not reflect social reality as it is popularly understood.

Yet, even if one accepts the view of the SSA prograin managers that a system which rehes upon bureaucratic rules will produce the best possible social outcomes (even though it diverges from what are commonly

56. Id. § 404.929 .

57. Mashaw, supra note 40 , at 33.

58. 20 C.F.R. $\S \S 404.955-.970$ (1989).

59. 42 U.S.C. $\S 405(\mathrm{~g})(1988) ; 20$ C.F.R. $\S 404.981$ (1989). Because disability awards are reviewed periodically by a state agency adjudication unit, benefits may be taken away once they are awarded. See id. $\S 404.1589$. If the claimant's award is termmated, she must jump through many of the same hoops all over again. See 42 U.S.C. $§ 404$ (1988); 20 C.F.R. $\S \S 404.501-.515$ (1989); see also Mashaw, supra note 40 , at 33.

60. This key social determination may turn on minor factors such as whether an AIJ has categorized the claimant as capable of "medium" or "heavy" work, whether a claimant is forty-eight or forty-nine years old, whether he has completed the eleventh or twelfth grade, or whether his job was operating one sort of machine or another. See 20 C.F.R. $\S 404$ Snbpart P app. at 2 (1989). 
understood to be significant factors), the system remains unfair. For example, the adoption of the grid system and closer monitoring of the state agencies by the SSA did dramatically reduce the lack of uniformity as to the application of vocational factors among state agencies. A 1976 General Accounting Office study revealed that in fewer than one-third of the cases studied was there complete agreenent among agencies as to whether a claim should be granted or denied, ${ }^{61}$ whereas the SSA now claims "accuracy rates" of $94.7 \% .62$ However, the remarkable improvement in the accuracy rates of the claims processors is deceptive. To the agency, "accuracy" means only that the case file had all of the documentation that management required, the processor correctly justified her factual conclusions with the grid rules, and the decision was not without factual support in the record. ${ }^{63}$

The high rate at which ALJs reverse the determinations of state claims processors denionstrates that the SSA's claims of "accuracy" are

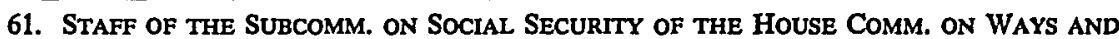
Means, 94Th Cong., 2D Sess., Disability Insurance-Legislative Issue Paper 9 (table 2) (Comm. Print 1976). The 1976 study by the General Accounting Office of the consistency of state agency disability determinations revealed that different government workers often came up with different results for the same applicant. The GAO randomly selected 221 disability claims that had been adjudicated by a state agency and then transmitted copies of the claims files to ten other state agencies and to federal adjudicators. In only $32 \%$ of the cases studied was there complete agrecment among adjudicators as to whether a claim should be granted or demied. In only 156 of the 221 cases was it possible for a majority of the state agencies to reach agrecment on whether to approve or deny the claim. Even when GAO conld find a majority of states im accord on the results of a case, it found that in $95 \%$ of those cases the states disagreed on the rationale for the decision. The federal adjudicators agreed with a majority of the states in fewer than half the cases. In nearly half the cases, state agencies and federal adjudicators believed that the furnished documentation was insufficient to reach a decision.

As to the ALJs themselves, one study stated that, "Variations in ALJ decisions [exist] for which no explanation has been found, other than differences in individual ALJ judgment and evaluation." J. MASHAW, supra note 11, at 3.

A New York Times article inade this point succinctly: "The Social Security disability program has become ... the most arbitrary of the Government's programs to help the needy, one in which poor people in similar circumstances often receive vastly different treatment." Rosenbaum, Huge Federal Disability Program Faces Inequities, Fund Woes, Suits, N. Y. Timies, July 27, 1977, at 1, col. 2.

62. 1989 SSA ANNUAL REPORT, supra note 12, at 32.

63. Accuracy rates are establislied through the "Quality Assurancc Review" procedure. In the review, case files are examined according to two issues: sufficiency of inedical evidence to make a determination; and, if sufficient, whether the determination was made correctly. The standard of review for these questions is deferential. For the determination of the sufficiency of medical evidence, the "probability of reversal" standard requires that the evidence be deemed sufficient unless it appears that more evidence would probably inandate a reversal. As to the determination itself, the SSA uses a "no substitution of judgment" standard. This standard requires that the state agency decision be deemed accurate if the decision is a reasonable one based upon the record; the reviewer is required not to substitute her judgment as to what the correct decision was if the original decision was supported on the record. Telephone interview with Mr. Thomas Grey, Department Director, Office of Disability Program Integrity and Review, Social Security Admm. (Jan. 4, 1989). 
probleinatic. In 1988, ALJs reversed the state determinations in $57 \%$ of the 258,421 cases they heard, ${ }^{64}$ and they reversed determinations at even higher rates for several particular categories of claimants. ${ }^{65}$ Not surprisingly, the overwhelming area of disagreement was the residual functional capacity of claimants. In these cases, the state officials almost always determined that "claimants were capable of inore vigorous work activity" than determined by the ALJs. ${ }^{66}$ Thus, although the Social Security Administration has created, through its review procedures, a uniform bureaucratic culture among the corps of state claims processors, it has not succeeded in forcing the ALJs - the group that is inost familiar with the SSA procedures and regulations, but not subject to its discipline-to conform. 67

To those who are unafraid of being pushy with government bureaucracies-those who can read all the fine print, represent theinselves articulately, and are not intimidated by coinplex forms and proceduresthe inany layers of review provided for in the present systein inay appear to offer adequate protection. The periodic review of those on the rolls may seen to be a reasonable safeguard against fraud. Yet inany people find inaneuverimg through the bureaucracy a daunting, if not impossible,

64. WAYS AND MEANS GREen BOOK, supra note 13, at 51.

65. General Accounting OfFice, Social SecuritY: Selective Face-To-Face INTERviews With Disability Claimants Could Reduce Appeals 3 (Pub. No. HRD-89-22, 1989).

66. Id.

67. Administrative Procedure Act, 5 U.S.C. $\$ \S 551-559,701-706,1305,3105,-3344,5372,7521$ (1988). The independence of ALJs is provided for by 5 U.S.C. $\$ \S 5372,4301-4303$ (1988). As the Supreine Court sees it, "[T]he process of agency adjudication is . . . structured so as to assure that the hearing examiner exercises his independent judgment on the evidence before him, free from pressures by the parties or other officials within the agency." Butz v. Econotnou, 438 U.S. 478, 513 (1978).

In an effort to force AIJs to stop "exercising their independent judgment," and force them to reduce the high levels of reversals of state agency denials of disability benefits, the SSA under President Reagan began reviewing the deeisions of ALJs with higher than average reversal rates. The agency attempted to coerce those judges to reduce their reversals. In response to litigation brought by the Association of Administrative Law Judges challenging the program's assault on their independence, the SSA backed off from this policy. See Association of Admin. Law Judges, Inc. v. Heekler, 594 F. Supp. 1132, 1141 (D.D.C. 1984); Stieberger v. Heckler, 615 F. Supp. 1315 (S.D.N.Y. 1985); see also GENERAL Accounting OfFICE, Briefing Report to THE CHAIRMAN, SUbCOMM.

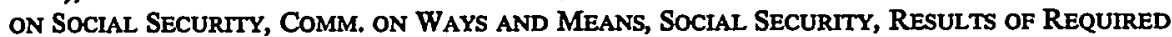
Reviews OF ADMINISTRATIVE LAW JUdGE Decisions 8-9 (1989) (GAO/HRD-89-48BR). Nevertheless, many ALJs continue to complain of liarassment by the Social Security Administration in efforts to get thein to deny more benefits. The SSA has taken away the secretaries and lawyers that reported to individual judges, and replaced them with persounel pools. Some judges charge that access to this pool is manipulated to discipline judges. The SSA also manipulates the assignments, travel arrangements, transfers, and other such matters as a method of disciplining AIJs. Ronald Bernoski, a Milwaukee ALJ and seeretary of the administrative law judges' association, cliarges that "[t]he agency lias consistently tried to control the ability of A.L.J.'s to function as independent adjudicators." Tolchin, Judges Who Decide Social Security Claims Say Agency Goads Them To Deny Benefits, N.Y. Times, Jan. 8, 1989, at 6, col. 1. 
task. Indeed, fewer than half of those initially denied benefits or terminated from the existing roles contest the bureaucracy's decision-despite the fact that more than half of those willing to fight their denial or termination ultimately prevail and receive benefits. ${ }^{68}$

Many of those who do not contest their denial or termination niay do so because they accept the legitiniacy of the agency's decision. But those unable or discouraged from doing so may include those nost in need. Given the legal hurdles that must be cleared, it is not surprising that sone Social Security Administration data suggests that appellants are "disproportionately white, middle-aged nnales with relatively nore recent and higher earnings than those who do not appeal."69 The further a claimant goes in the systen, the greater his chances of receiving benefits. ${ }^{70}$ Thus, those who can best understand and afford the numerous appeals that the systen allows-white, iniddle aged, higher earning niales-are those most likely to receive their benefits. It is an indictnient of the procedures that class and race play a significant role in determining the assignment of benefits.

\section{What Process Is Due?}

To the SSA administrators and to those who appreciate and accept the compromises of the legislative process, the congressional choice as to who is to be covered by the disability program may inake sense. The holes in the social safety net are the unfortunate result of the give-andtake of lawmaking. But to the disabled individual who knows full well that his condition prevents him from getting or keeping a job, the program operates unfairly. A democratic society promises, in part, that important governmental determinations will be nrade according to criteria that are understood as fair by the general public, not simply by those in positions of power and privilege.

In the 1960s, the Supreme Court greatly expanded the procedural protections accorded individuals in their dealings with the governnent. In the administrative context, this expansion reached its culmination in 1970 in the watershed case of Goldberg v. Kelly. ${ }^{71}$ In Goldberg, Justice Brennan acknowledged that in the modern administrative state, interests

68. WAYS AND MEANS GREEN BOOK, supra note 13, at 51 .

69. J. MASHAW, supra note 11, at 138 (citing Treitel, Disability Claimants Who Contest Denials and Win Reversals Through Hearings, Div. of Disability Studies, No. 3 (mimeo 1979) Office of Research and Statistics Working Paper Series, Soc. Security Admin., Dep't of Health, Educ. \& Welfare.) Attempts to procure more recent data from the SSA through the Freedom of Information Act proved fruitless. Officials at the SSA FOIA office insisted that there have been no studies on this subject since the above.

70. See Ways AND MEans Green Book, supra note 13, at 51.

71. 397 U.S. 254 (1970). 
such as entitlements, franchises, professional licenses, and the like, are as vital to people today as "vested rights" were to people of the founding fathers' and inothers' generation. ${ }^{72}$ The Goldberg Court held that before terminating a government benefit-at least in the context of social welfare benefits-due process requires the holding of a pretermination hearing, the provision of adequate notice, and the granting of the right to confront adverse witnesses. ${ }^{73}$

The conservative backlash came quickly. Just two years after Goldberg, in the landinark case of Board of Regents v. Roth, the Court demonstrated that the tide of rights expansion had turned. ${ }^{74}$ The Justices in the inajority apparently were concerned that the demise of the right-privilege distinction, ${ }^{75}$ coupled with the traditionally expansive interpretation of "liberty and property, ... would make the [Fifth and] Fourteenth Amendinent[s] a font of tort law to be superimposed upon whatever systens may already be administered by the States [and the Federal government]." 76 Those Justices 77 no doubt were concerned that the expansion of the administrative state, which led to an increased reh-

72. Id. at $262 \mathrm{n} .8$ (citing Reich, Individual Rights and Social Welfare: The Emerging Issues, 74 YAle L.J. 1245, 1255 (1965)); see also Reich, The New Property, 73 YAle L.J. 733 (1964).

73. Id. at $267-68$.

74. 408 U.S. 564 (1971).

75. Under the doctrine of the right-privilege distinction, courts reasoned that because The Bill of Rights and the fourteenth amendment offered no protection to unfairly treated individuals from the actions of private parties, these constitutional rights similarly did not apply when the governinent operated by inethods more characteristic of the private sector-for example, by contract, lease, as an employer, or as a charitable contributor-rather than by the more settled method of general legislation. See Van Alstyne, Cracks in "The New Property": Adjudicative Due Process in The Administrative State, 62 CORNELL L. REv. 445, 486 (1977).

The best known appearance of the right-privilege doctrine dates from 1892, in the famous dictum of Justice Holmes (then speaking for the Supreme Judicial Court of Massachusetts) dismissing the claim of a person who had been fired for having violated a police department regulation forbidding even off-the-job political comment:

The petitioner may have a constitutional right to talk politics, but he has no constitutional right to be a policeman. There are few employments for hire in which the servant does not agree to suspend his constitutional rights of free speech as well as of idleness by the implied terms of his contract. The servant cannot complain, as he takes the employment on the terms which are offered him.

McAuliffe v. Mayor of New Bedford, 155 Mass. 216, 220, 29 N.E. 517, $517-18$ (1892).

Similarly, although the popular mythology of America would have it that the right to frce speech in the pubhic parks is an ancient right, such is not the case. Agaim, Justice Holmes held: "For the legislature absolutely or conditionally to forbid public speaking in a highway or public park is no more an infringemeut of the rights of a inember of the public than for the owner of a private house to forbid it in his house." Commonwealth v. Davis, 162 Mass. 510, 511, 39 N.E. 113, 113 (1895).

Similarly, just as a private citizen could condition her charitable contributions in a manner that is unfair, or conditioned upon the restriction of constitutional rights, so too could the government. See L. Tribe, American Constitutional Law § 10-8, at 680-81 (2d ed. 1988).

76. Paul v. Davis, 424 U.S. 693, 701 (1976).

77. Justice Rehnquist joined by Chief Justice Burger and Justices Powell, Blackmum and Stewart. 
ance on government benefits, would provide the basis for an increased number of challenges to government procedures for apportioning those expanded benefits. Despite their concerns, the Roth Court accepted the demise of the right-privilege distinction: "[T]he Court has fully and finally rejected the wooden distinction betwecn 'rights' and 'privileges' that once seemed to govern the applicability of procedural due process rights."78 But although the Roth Court rejected this wooden distinction-which allowed the applicability of procedural rights to turn on whether a government action was characterized as conferring a "right" or a "privilege"-it now held that procedural rights turn upon whether the imterests affected by a government action are characterized as cognizable "liberty" or "property" interests, or as merely "expectancy" interests. ${ }^{79}$ Justice Stewart, writing for the inajority, held that before a reviewing court could determine the procedural protections due an individual, the court "must look not to the 'weight' but to the nature of the interest at stake. We must look to see if the interest is within the [Fifth or] Fourteenth Amendment's protection of liberty and property."80 Under this formulation, a citizen has no redress for even the inost grossly unfair procedures unless the reviewing court holds that the underlying interest being adjudicated rises to the level of a liberty or property interest-a standard that has become increasingly inore narrow. 81

In Goldberg, Justice Bremian argued that a court must look beyond whether the interest affected by government action constitutes property. Justice Bremian urged that a court ask: To what extent governmental interests may condemn an individual to "suffer a grievous loss"82 yet remain consistent with this nation's commitment to the "dignity and well

78. 408 U.S. at 571 (citation omitted).

79. Id. at 577 ("To have a property interest in a benefit, a person ... must have inore than a unilateral expectation of it. He inust, instead, have a legitimate claim of entitlement to it."); see, e.g., Kentucky Dep't of Corrections v. Thompson, 109 S. Ct. 1904, 1910-11 (1989) (because prisoner's interest in receiving visitors is not a legitimate claim of liberty entitlement, no procedural protections are due); Board of Pardons v. Allen, 482 U.S. 369, 382 (1987) (O'Comor, J., dissenting) ("[M]ere expectation of a benefit-even if that expectation is supported by consistent government practice-is not sufficient to create an interest protected by procedural due process."); Perry v. Sinderman, 408 U.S. 593, 599-603 (1972) (mere "expectancy" that teacher's contract would be renewed is not protected by procedural due process unless a contract exists creating a property entitlement).

80. 408 U.S. at 571 (citation omitted).

81. In Roth itself, the Court held that Mr. Rotll, a college teacher fired for exercising his first amendment rights, was not entitled to even the most minimal procedural protections when his contract was not renewed. $I d$. at 578.

In Paul v. Davis, 424 U.S. 693 (1976), the Court held that the liberty clause did not apply when a police department distributed a person's name and photo to local department stores as an "active shoplifter." Relying on Roth, the Court held that state defamation of a private individual "standing alone and apart from any other governmental action" did not implicate the "hiberty" protected by the due process clause. Id. at 694,712 .

82. Goldberg v. Kelly, 397 U.S. 254, 263 (1970). 
being of all persons within its borders." 83 Justice Brennan argued that the constitutional right of due process exists to protect the dignity and welfare of citizens.

To most Americans, the constitutional right to "due process" means the right to be treated fairly when we interact with the government. But in specific situations, what precess is due? Intuitively, we suspect that what qualifies as procedurally "fair" depends to some extent on the nature of the underlying decision. In many contexts, bureaucratically rational bright lines-lines that are inherently arbitrary at the margin-are acceptable. For example, although soine minors are more responsible, intelligent, and possess quicker reflexes than some adults, few would suggest that fundamental fairness requires granting minors even the inost perfunctory hearing over the demial of their right to drink alcohol, vote in elections, cr drive motor vehicles. In other contexts, it is pohtically acceptable to grant decisionmakers broad discretionary powers. Public prosecutors, for example, are granted discretion in their decisions on whether to prosecute. ${ }^{84}$ Indeed, the elected executive branch's very function is to exercise its discretion on policy implementation.

The disability decision is a judgnient of considerable social significance. The judgnient is one that the claimant does, and society should rightly perceive as having substantial moral content. ${ }^{85}$ In a capitalist system, those without access to income are under a financial and moral imperative to work. Thus, entitleinent programs determine eligibility not by insufficiency of income, but rather by excuses for non-participation im the work force-old age, injury, and disability. A grant of disability benefits signifies an cfficial stamp of appreval of the claimant's status as a non-worker. Conversely, the demial of a disability claim effectively brands the claimant as a malingerer: Her claim is socially illegitimate and does not entitle her to an excuse from the work force.

These moral and status dimensions of the disability decision tell us that more is at stake-both to the claimant and to the values of society as a whole-in disability claims than just the temporary loss of income. This view, when read in conjunction with the many nonmedical criteria used in the disability determination, suggests that the disability decision must be understood within a broader framework-a framework that rejects both the superficial conclusion that disability decisions are a routine matter of evaluating medical evidence, ${ }^{86}$ and the assumption that the disability determination problem can be surmounted by achieving "cbjec-

\footnotetext{
83. Id. at 265 .

84. W. Lafave and J. Israel, Criminal Procedure § 13.2(a), at 561-63 (1985).

85. Mashaw, supra note 40 , at 51.

86. Id. at 52 .
} 
tive" accuracy. In spite of all the technical rules, the disability decision still rests upon subjective factors. ${ }^{87}$ Yet, even if the determinations could have technically "correct" outcomes, when making decisions with imphcations concerning an individual's "moral worth," a democratic notion of fairness requires that popular values must be imcorporated in the determination of what process is due.

Fairness in a government program has, of course, a substantive as well as a procedural dimension. But even a program with substantively fair outcomes must address how its procedures make individuals feel. A sense of the illegitimacy and unfairness in the inanner of determination in government actions that brand an individual a malingerer will not be dissipated by informing that person that the impersonal and alienating bureaucratic procedures utilized in making that decision is as objectively accurate as efficiency permits. The perception that natural justice includes the imdependent right to tell one's tale at a fair tribunal is as old as civilized society itself. ${ }^{88}$ In a democracy, the procedural process due to an individual can only be legitimately determined by the community's sense of fairness. To the extent that agency procedures are not consistent with what most people think justice requires, those procedures are unfair. Thus, the operation of many programs of the administrative state may violate the community's definition of justice, thereby implicating notions of due process.

\section{Can Judges Impose Due Process: Pragmatic, STRUCTURAL, AND IDEOLOGICAL RESTRAINTS}

The reluctance of the courts to mandate sweeping changes in the processes and values of social welfare institutions is understandable. The structural and pragmatic limitations under which the judges labor-as

87. See J. MASHAW, supra note 11, at 51-52; see also infra notes $145-52$ and accompanying text;.

88. Our common law tradition has long supported this proposition. See, e.g., Magna Carta $\S$ XXXIX, in J. Holt, MAGNA CARTA 327 (1965). British administrative law recognizes this human need. H.W.R. WADE, ADMINISTRATTVE LAW 465 (6th ed. 1988). A form of the right to confrontation was recognized in England well before the right to jury trial. Pollitt, The Right to Confrontation: Its History and Modern Dress, 8 J. PUB. L. 381, 384-87 (1959). Shakespeare discussed the right of parties to speak freely at a tribunal. W. SHAKESPEARE, Richard II, act 1 , sc. $\mathrm{i}$, in THE COMPLETE Works of SHAKespeare 758 (D. Bevington ed. 1980). This right also seems to have existed in soine form in ancient Egypt, The Instruction of Ptahhotep (Egyptian 6th Dynasty, 2300-2150 B.C.), reprinted in Mashaw, Administrative Due Process: The Quest for a Dignitary Theory, 61 B.U.L. Rev. 885 (1981). Probably the inost famous ancient example of a party defending himself is that of Socrates given to the court of 501 of his fellow citizens for the crimes of impiety and corrupting the young inen. Plato, The Apology, in The Collected Dialogues of Plato 5 (E. Hamilton and H. Cairns ed. 1956). See generally I.F. STONE, THE TRIAL OF SOCRATES (1988), 
well as the ideology of the judiciary-militate against judges redefining the role of administrative agencies.

This Part first explores the pragmatic and structural restraints on judicial power. Section A argues that often judges can do little to directly improve the fairness of flawed bureaucratic institutions. Section $\mathbf{B}$ examines the current ideology of legal process that serves to restrain judges from acting indirectly, through political expressions, to amehiorate substantive problems in the society. I argue that the currently dominant professional ideology that restrains judges from speaking out to influence policy are pernicious and ahistorical. Part III concludes with a call for judges to pursue an active role in the articulation and development of constitutional values.

\section{A. Pragmatic and Structural Restraints on Judicial Power}

Pragmatic and structural restraints on the exercise of power by courts limit the ability of judges to alter the structure and values of administrative agencies. The judiciary lacks the power of the purse and the power to engage in extended fact finding, nor does it possess the power to create and oversee large institutions. ${ }^{89}$ Judges do have the power to order an agency to adhere to certain procedures, but they have little power to keep an agency from going out of existence-or from transforming itself altogether..$^{90}$ And assuredly the courts lack the power to inandate the creation of new multi-billion-dollar agencies.

More subtly, legal conventions mandate that lawyers and judges approach issues in ways that tend to constrain what can be done through the courts to effect changes in public policy. The traditional discourse of rights and balancing tests limit judges' ability to analyze and challenge the constitutional substance, as well as the procedures, of the creations of legislative and executive power, i.e. administrative agencies. If an agency is fundainentally flawed, contradictory in purpose and inandate, and unfair to those whose lives are touched by it, then there is often bittle that the courts can do about it.

89. Compare U.S. CoNsT. art. I, \& 8 ("The Congress shall have Power To lay and collect Taxes ... to pay ... for the ... general Welfare of the United States . . To make all Laws which shall be necessary and proper for carrying into Execution ... all ... Powers vested by this Constitution.") and id. art. II, $\S 1$ ("The executive Power shall be vested in a President of the United States of America.") with id. art. III (containing no such powers).

90. See, e.g., Palmer v. Thompson, 403 U.S. 217 (1971). Palmer held that because there is no "affirmative duty" on the part of the government to operate swimming pools, the City of Jackson, Mississippi had not acted unconstitutionally in closing its public swimming pools after they had been ordered desegregated. But see Griffin v. County School Bd., 377 U.S. 218 (1964) (holding that although a county could choose to close down its public schools, it could not do so for an unconstitutional purpose, and avoiding desegregation was an unconstitutional purpose). 
To be sure, federal judges occasionally have succeeded in dramatically altering a public institution in ways that have substantially improved the lives of tlose touched by it. The prison reforn cases are the most notable example. ${ }^{91}$ Such successful intervention in institutional life has, however, been exceptional. The political reality in those cases was quite different than in the social welfare context. Prison officials and state legislators may liave wanted to resist federal judicial orders, but they were not about to allow the affected prisons to shut down altogether. But in the context of services delivered to the public, particularly social services to the poor, the end results of inost judicial interventions have been much inore problematic. ${ }^{22}$

1. The Inadequacy of Procedural Reform. The limited ability of the courts to reforn and recast institutions through procedural reform is exemplified by the subsequent history of the Supreme Court's decision in Goldberg v. Kelly. ${ }^{93}$ The Goldberg Court held that the interest of the eligible recipient in the uninterrupted receipt of public assistance, coupled with the state's interest that his paynents not be erroneously terminated, clearly outweiglis the state's competing concern to prevent any increase im its fiscal and administrative burdens. ${ }^{94}$ The decision further held that due process requires a pre-termination liearing, adequate notice, and the right to confront adverse witnesses. ${ }^{95}$ However, the responses of both the Goldberg majority and dissent were inadequate to the task of ameliorating the unfairness of New York's welfare program. On the one hand, the majority's attempt to reform the system ultimately proved ineffectual: The Court could mandate changes in the adjudicatory procedure for the termination of benefits, but it lacked the ability to modify the substance of the prograin. On the otlier hand, if the Court had accepted Justice Black's stance of restraint, as expressed in his dissent, it would have legitimated an unfair system. Nevertlieless, Goldberg

91. See, e.g., Hutto v. Finney, 437 U.S. 678 (1978) (upholding the detailed remedial scheme ordered by the district court following its finding that the conditions in the Arkansas penal system violated the eighth amendment).

92. Some might argue that the elimimation of de jure public school segregation is a paradigmatic example of the success that federal judicial intervention can have in institutional life. Yet, given the abysmal state of public school education that exists in America, particularly in poor African American neighborhoods, as well as the remarkably high level of segregation that continues to exist-now de facto-this conclusion is problematic. Professor Peller further argues that in addition, judicial intervention in public schools has had a negative effect on African American institutional life and has eroded the position of those who formerly led such institutions. See Peller, Race Consciousness, 1990 DuKE L.J. 758, 779-83.

93. 397 U.S. 254 (1970).

94. Id. at 263.

95. Id. at 267.68 . 
articulated a vision of how the community ought to view government interaction with citizens. ${ }^{96}$

In Goldberg, Justice Brennan interpreted due process as the processes that are to be accorded hunian beings consistent with their diginty as individuals. To the Goldberg inajority, the government itself isor should be-primarily interested in ensuring that all eligible persons receive their benefits and that agency procedures to determine benefit allocation are consistent with the individual's dignity and the community's sense of fairness. ${ }^{97}$

Interestingly, in this pre-Roth, post-right/privilege distinction era, the state did not challenge the recipients' entitleinent to welfare benefits or the applicability of procedural due process protections to the receipt of those benefits. The welfare administrators argued that the individual's interests were outweighed by the countervailing governmental interests in conserving fiscal and administrative resources. The Goldberg majority agreed that efficiency is an important governmental niterest: "We wish to add that we, no less than the dissenters, recognize the importance of not imposing upon the States or the Federal Government . . . any procedural requireinents beyond those demanded by rudimentary due process."98 Nevertheless, the Court held rudimentary due process deinanded procedural protections that were considerably greater than those provided by New York's welfare administration: "[T]he interest of the eligible recipient in uninterrupted receipt of public assistance, coupled with the State's interest that his payinents not be erroneously termi-

96. In a 1987 speech to the New York Bar Association, Justice Brennan argued that:

If due-process values are to be preserved in the bureaucratic state of the late 20th century, it may be essential that officials possess passion-the passion that puts thein in touch with the dreams and disappointments of those with whom they deal. . . . Goldberg can be seen as injecting passion into a system whose abstract rationality had led it astray.

Greenhouse, New Look at an "Obscure" Ruling 20 Years Later, N.Y. Times, May 11, 1990, at B12, col. 3.

97. Goldberg v. Kelly, 397 U.S. 254, 264-65 (1970). Justice Brennan wrote that:

[I] inportant governmental interests are prounoted by affording recipients a pre-termination evidentiary hearing. From its founding the Nation's basic commitment has been to foster the dignity and well-being of all persons within its borders. We have coine to recognize that forces not within the control of the poor contribute to their poverty.... Welfare, by meeting the basic demands of subsistence, can help bring within the reach of the poor the same opportunities that are available to others to participate meaningfully in the life of the community ... . Public assistance, then, is not inere charity, but a means to "proinote the general Welfare, and secure the Blessings of Liberty to ourselves and our Posterity." The same governmental interests that counsel the provision of welfare, counsel as well its uninterrupted provision to those eligible to receive it; pre-termination evidentiary hearings are indispensable to that end.

Id. at 264-65 (citations and footnotes onnitted).

98. Id. at 267. 
nated, clearly outweighs the State's competing concern to prevent any increase in its fiscal and administrative burdens."99

Goldberg v. Kelly seeined to promise that individuals would be provided with elaborate procedural protections before they could be denied government benefits. Courts have failed to follow through on the promise of Goldberg v. Kelly; in the Social Security disability context, rudimentary due process requires much less than was required by Goldberg. The Goldberg Court may have contributed to this failure by its inability to usher in positive reforms of the welfare bureaucracies. Although procedural protections from benefit terminations for social service claimants are greater today than they were twenty years ago, the procedures for getting benefits are inuch inore bureaucratic and difficult. Society's coinmitinent to the war on poverty has been eroded-destroyimg the substantive hope behind the procedural promise. Justice Black's dissent in Goldberg proved prescient:

[T] he Court apparently feels that this decision will benefit the poor and needy. In my judgment the eventual result will be just the opposite. ... Thus the end result of today's decision may well be that the government, once it decides to give welfare benefits, cannot reverse that decision until the recipient has had the benefits of full administrative and judicial review .... . Since this process will usually entail a delay of several years, the inevitable result of such a constitutionally imposed burden will be that the government will not put a claimant on the rolls imitially until it has made an exhaustive investigation to determine his eligibility. While this Court will perhaps have insured that no needy person will be taken off the rolls without a full "due process" proceeding, it will also have insured that many will never get on the rolls, or at least that they will remain destitute during the lengthy proceedings followed to determine initial eligibility. ${ }^{100}$

The procedures for getting on the welfare rolls have become increasingly bureaucratized and difficult; ${ }^{101}$ social workers have dropped out of the welfare process and welfare clerks have taken over the imcreasingly cumbersome, impersonal and depersonalizing welfare determinations. ${ }^{102}$

99. Id. at 266 .

100. Id. at 278-79 (Black, J., dissenting).

101. J. Mashaw, Due Process in the Administrattve State 33-34 (1985).

102. Id. Kathy Porter of the Center on Budget Priorities suggests that the Reagan Adininistration's emphasis on error rates and threats to cut off state funding in the event of excessive error rates, which includes files deened incomplete, were the inain reason for the increasing bureaucratization of the welfare process. Telephone interview with Kathy Porter, Staff Meniber, Center on Budget and Policy Priorities (Dec. 18, 1989). The recently enacted Family Support Act of 1988, Pub. L. No. 100-485, 102 Stat. 2343 (codified in scattered sections of 42 U.S.C.), may partially reverse this trend by allowing states the option of establishing a case management approach to welfare. 
Already inadequate benefit levels remained relatively static, while inflation ate away purchasing power. ${ }^{103}$

Justice Black, as a former pohtician and legislator, recognized the structural and political limitations on the Court's ability to reform and recast institutions. As the country's shift to the right set the agenda, Goldberg's promise becaine imcreasingly meaningless. The history of Goldberg thus demonstrates the material limitations of utilizing procedural reform to attack substantive problems. Moreover, its discourse has proved thoroughly manipulable; although never overturned, it has been distinguished out of existence. Both practically and rhetorically, it has become peripheral to the lives it was most meant to toucli.

\section{Case-By-Case Review: Full of Sound and Fury but Signifying} Little. Another structural restranit on the role of judges is the way im which issues come before a judge-one case at a time. By the time a claimant reaches federal court, slie already will have expended much time and effort to get througl agency proceedings. The judge will not coinpensate the claimant for her efforts. The judge will not order the SSA to tailor a rehabilitative progran for the claimant, or to change its practices so that soine future similarly situated claimant also is not mishandled. The judge will not order the government or society to create a job appropriate to the claimant's needs. Some may argue that the above is precisely what a judge should do. Practically speaking, however, under our system it seems likely that such judicial efforts would fail. Thus, all the judge will do is determine whetler or not the claimant will receive benefits. ${ }^{104}$ Altlough the benefit determination is relevant to the individual claimant, it is of hittle relevance to tlie transformation of the flawed institution.

At the level of policy reform, it would seem that federal district court judges are in an excellent position to mandate incremental reforms to inake the administration of disability benefits more fair and less ahenating. District court judges review many disability determination cases-im 1988 an average of twenty disability cases per district

103. Between 1970 and 1989 the AFDC maximum welfare benefit for a typical family in the median state shrank by $37 \%$ after inflation. WAYS AND MEANS GREEN BooK, supra note 13, at 546-47. Between 1960 and 1987 the decline was 27.5\%. STAFF OF THE HOUSE COMM. ON WAYS and Means, 100Th Cong., 2D Sess., Background Material and Data on Programs WITHIN THE JURISDiction OF THE CoMmitTeE ON WAys AND MEANS 688 (Comm. Print 1988).

104. The regulations are sufficiently indeterminate so that even under the deferential substantial evidence standard of review individual judges are free to do justice in individual cases. That is to say, with good people as federal judges case-by-case review will bring justice to the individuals who make it to court. 
judge ${ }^{105}$ _and thus must see the same problems presented over and over. The judges are well informed in the areas in which incremental improvements could be made. Leaving aside for the moment the issues of the reform of the administration and mission of the SSA, district court judges could play an incremental policy developinent role in the administration of the SSA. But such a role would require that judges understand that the cases that come before them are not mere aberrations of a wellfunctioning and fair system. Cases require more than the articulation of the standard tests and the "determination" of whether a particular case has satisfied the tests. Judges need to understand that the problems they see are systemic and, as such, require systemic intervention for their solution.

For example, a number of courts have articulated the primciple that an ALJ has an affirmative duty to assist a pro se claimant in developing his case. ${ }^{106}$ Most judges, however, smiply state this "rule" and determine whether it was followed in the particular case. A number of courts have decided cases based on a defective or inadequate notice of the right to counsel-without ordering that the agency in the future follow any specific procedures in giving notice. ${ }^{107}$ Compared to desegregating a school district or the many other occasions whereupon the federal judiciary has seen fit to exercise its equitable powers in public law areas, giving detailed, working regulations for Social Security adjudicators to follow seems rather simple. A hittle less restramt on the part of the federal bench could result in the development of fair procedures for the bulk of claimants. Clearly, federal judges have the power to do inore than determine whether a rule was followed in a particular case: Judges may order

105. This number is derived by dividing the number of disability cases by the number of district judges. 1989 ADMINistrattve OFFICE ANNUAL REPORT, supra note 16, at 5 (Commentary, "Civil Workload"); id. at 23 app. 1 (table C-2).

106. See, e.g., Sherrer v. Secretary of the Dep't of Health and Human Servs., 575 F. Supp 1503, 1504 (S.D.N.Y. 1983) (ALJ has affirmative obligation to assist pro se claimant in developing clinical findings in worker disability case); Tingling v. Dep't of Health and Human Servs., 575 F. Supp. 905, 909 (S.D.N.Y. 1983) (ALJ duty to explore all relevant facts and develop record is particularly important where claimant appears pro se); Remecke v. Schweiker, 554 F. Supp. 1102, 1103-04 (E.D.N.Y. 1983) (when a social security claimant is not represented by counsel, ALJ is under a heightened duty to scrupulously and conscientiously probe into and inquire of and explore all relevant facts); Capoferri v. Harris, 501 F. Supp. 32, 38 (E.D. Pa.) (ALJ has special responsibility with respect to unrepresented claimant), aff'd, 649 F.2d 858 (2d. Cir. 1980).

107. See, e.g., Simgleton v. Schweiker, 551 F. Supp. 715, 721 (E.D. Pa. 1982) (failure of claimant to receive notice during administrative proceeding that free counsel was available to indigents rendered notification of right to counsel inadequate); Saldana v. Weinberger, 421 F. Supp. 1127, 1132. 33 (E.D. Pa. 1976) (ALJ should state that counsel is available without charge to indigents). 
that specific procedures be followed and may appoint special masters to detail regulations and oversee their enforcement. ${ }^{108}$

Even at the level of superficial pohicy reform, however, the probleins are deeper than mere judicial timidity. Several practical problems make judicial intervention difficult and possibly irrelevant. First, under the reigning conventions of American pohtics, pohicy generally is viewed as legitimately determined by the discretion of the legislative and executive branches. Judicial invalidation is viewed as legitimate only when a policy can be said to be "fundamentally" unfair. Thus, the effective power of a judge is limited by the conventional understanding of the proper role of the judge. The support of other political actors is necessary to give effect to a judge's orders.

Second, it may be difficult for courts to implement their views effectively without becoming engrossed in the day-to-day operations of the program. Subtle but powerful management actions-such as the budget for claims examinations and the setting of productivity goals for examiners-shape the adjudicatory culture. ${ }^{109}$ These policies, sometimes called the "management side of due process," have little obvious bearing on the outcome of particular cases, but markedly affeet the gross award and demial rates. ${ }^{110}$ Judges imght well have to substantially broaden their role to effect changes at this level. ${ }^{111}$

108. It is an equity axiom that no man shall be denied a remedy if he is wronged. $J$. O'CONNELL, REMEDIES 47 (1985). To combat unconstitutional segregation, courts have involved themselves in the day-to-day operations of many institutions, see, e.g., Brown v. Board of Educ., 349 U.S. 294 (1955) (directing lower courts to fashion and effectuate desegregation decrees). Federal district courts also have embroiled themselves in the management of prisons, see, eg., Hamilton v. Schiro, 338 F. Supp. 1016 (E.D. La. 1970), further relief ordered sub nom. Hamilton v. Landrieu, 351 F. Supp. 549 (1972), as well as in many other circumstances. See D. HorowrT, supra note 6, at 4.

Some might argue that a broad reading of Vermont Yankec Nuclear Power Corp. v. NRDC, 435 U.S. 519 (1978), would mandate that courts not dictate specific procedures to administrative agencies. Vermont Yankee held that reviewing courts are generally not free to impose greater procedural protections than those delineated by the Administrative Procedure Act. Id. at 546. Although deferenee to agency procedures generally may be required, such a broad reading of Vermont Yankee is unwarranted, even in cases without unpact on significant individual constitutional rights. See, e.g., Motor Vehicle Mfrs. Ass'n. v. State Farm Mut. Auto. Ins. Co., 463 U.S. 29, 41 (1983) (in order to determine if agency action is not arbitrary and capricious under the APA's standard of review, agencies must have procedures that allow such review to be neaningful, and agencies justifications will be upheld only if rational).

109. J. MASHAW, supra note 11 , at 187.

110. Id. See also Mashaw, The Management Side Of Due Process: Some Theoretical and Litigation Notes on the Assurance of Accuracy, Fairness, and Timeliness in the Adjudication of Social Welfare Claims, 59 CORNELl L. REv. 772 (1974) ("'nrass-produced" rights shonld change the way we think about due process).

111. Moreover, the trend in the Supreme Court's standing doctrine secms to be to deny standing for suits that seek to enjoiu governmental activities when the claim is that it is only the incentives, rather than the proximate cause, of the challenged activity that is causing illegal outconres. Thns, it 
Moreover, as the discussion of Goldberg demonstrates, ${ }^{112}$ we should not be too optimistic about the effects of judicial involvement in agency management. Particular issues might be too comrected with other aspects of the system's operations to permit smooth integration of judicial reinedies. For example, in several jurisdictions federal judges have in1posed time limits on hearing decisions in disability cases. ${ }^{113}$ Ordering the speed-up of disability decisions seems, of course, a salutary change. A study revealed, however, that a secondary effect of speeded-up hearings was a reduction in the overall quality of the process-a consequence of a speed-up unaccoinpamed by funds for additional personnel. ${ }^{114}$ Thus, judicial efforts to improve the process without actively participating in the day-to-day oversight of the agency inay make the whole process worse. ${ }^{115}$

Finally, at least in the past, the SSA has not considered itself bound by the rules of stare decisis and collateral estoppel: That is, the SSA has refused to give lower court rulings precedential effect. The SSA seems to think that it may flout the mandates of the federal courts. ${ }^{116}$ The SSA's former pohicy concerning the treatinent of judicial precedent was laid bare im an Office of Hearings and Appeals handbook:

[W] here a district or circuit court's decision contains interpretations of the law, regulations, or rulings which are inconsistent with the Secretary's interpretations, the ALJs should not consider such decisions binding on future cases. ...

seems that even if a judge were inclined to embroil herself in the management side of due process, she might have to deny standing to litigants attempting to bring such a suit. See, e.g., Allen v. Wright, 468 U.S. 737, 766 (1984) (parents of African American public school children without standing to challenge IRS lack of enforcement of demal of tax exempt status to racially restrictive public schools; article III bars suits of speculative imjury); Simon v. Eastern Kentucky Welfare Rights Org., 426 U.S. 26, $42-46$ (1976) (Court demies standing to welfare plaintiffs challenging IRS ruling granting charitable status to hospitals that refused service to indigent patients; injury found not to be sufficiently traceable to the challenged action despite marked changes in refusal rate following policy); Warth v. Seldin, 422 U.S. 490, 504-06 (1975) (potential low income residents have no standing to challenge economically restrictive zoning; economic factors, as well as the zoning, led to exclusion).

112. See supra notes $93-103$ and accompanying text.

113. See, e.g., White v. Mathews, 559 F.2d 852, 860 (2d Cir. 1977) (district court's imposition of a time schedule is consistent with congressional expectations).

114. Sometimies forty or more liearings were held each day, thereby reducing the claimant's "day" in court to about ten minutes, and corners were cut-such as not contacting doctors or updating rccords-in order to comply with the order. J. MASHAw, supra note 11, at 187-88.

115. Id.

116. Judge McMillian of the Court of Appeals for the Eighth Circuit declared that if the Secretary persisted in pursning non-acquiescence in that court of appeals, he would seek to bring contempt proceedings against her, both in her official and her mdividual capacities. Hillhouse v. Harris, 715 F.2d 428, 430 (8th Cir. 1983) (McMillian, J., concurring). 
When SSA decides to acquiesce in a district [or] circuit court decision, which is inconsistent with our previous interpretation . . . SSA will ... promptly advise[ ] [ALJs] of such action. ${ }^{117}$

The pernicious effects and possible illegality of the SSA's refusal to obey court rulings manifested itself during the crisis over the Continuing Disability Review (CDR), discussed below im the examination of Schweiker v. Chilicky.118 The United States Court of Appeals for the Ninth Circuit twice ruled that the CDR pohicy of de novo redetermination of benefits conflicted with the Social Security Act.119 The SSA, however, refused to change its practice, in the Ninth Circuit or anywhere else, except in the cases specifically decided. ${ }^{120}$ In the words of then SSA general counsel, "[T]he federal courts do not run SSA's programs. ..."121

The SSA is not the only agency to practice non-acquiescence. The Internal Revenue Service (IRS) and the National Labor Relations Board (NLRB) both have such pohicies ${ }^{122}$-pohicies which have been sharply criticized by the courts. ${ }^{123}$ The IRS's policy, however, is quite different from that of the SSA. The IRS follows circuit court decisions within the jurisdiction of the circuit; its non-acquiescence ruling only indicates that it may clioose not to follow the precedent of one circuit court in another circuit. In contrast, the SSA simply has declined to follow the decisions of the district or circuit courts in future cases. ${ }^{124}$ Although the Disability Reform Act of $1984^{125}$ as enacted did not contain a provision that was included in its originally introduced form that wonld lave outlawed the

117. J. MASHAW, supra note 11 , at $186-87$ (quoting OfFICE OF HEARINGS AND APPEALS HANDBOOK § 1-161 (1982)).

118. 487 U.S. 412 (1988). See infra notes 163-75.

119. See Patti v. Schweiker, 669 F.2d 582 (9th Cir. 1982); Finnegan v. Mathews, 641 F.2d 1340 (9th Cir. 1981).

120. J. MASHAW, supra note 11 , at 186.

121. Id. (quoting Associate Commissioner Office of Hearings and Appeals, Memorandum, "AIJ Pohcy Council Meeting," at 2 (Jan. 7, 1982)) (available from author).

122. See generally Vestal, Relitigation by Federal Agencies: Conflict, Concurrence and Synthesis of Judicial Policies, 55 N.C.L. REV. 123, 123 (1977) (relitigation is a regular and debilitating occurrence).

123. See, e.g., Ithaca College v. NLRB, 623 F.2d 224, 228 (2d Cir. 1980) (court's decision binds NLRB so long as Supreme Court does not reverse), cert. denied, 449 U.S. 975 (1980).

124. The IRS generally follows a policy of litigating the same issue in several circuits to create a split among the circuits and thereby create a ground for Supreine Court review. See Williams, The Social Security Administration's Policy of Non-Acquiescence, 12 N. KY. L. REV, 253, 262-63 (1985) (discussing the Social Security Administration's and other administrative agencies' policies of nonacquiescence).

125. Pub. L. No. 98-460, 98 Stat. 1794 (1984) (codified in scattered sections of 42 U.S.C.); see also infra notes $169-70$ and accompanying text. 
SSA non-acquiescence, 126 the Conferees' report indicated that non-acquiescence was permissible only in situations in which review of the disputed issue was to be sought in the Supreine Court. The Conferees also urged the Secretary to seek a resolution of the non-acquiescence issue in the Supreme Court. ${ }^{127}$ In addition, the Administrative Conference of the United States in 1988 published a draft recommendation on agency nonacquiescence that was highly critical of the SSA's position. ${ }^{128}$ In late 1988, SSA finally proposed regulations im which it agreed to follow circuit court decisions, but not those of the district courts, and only in courts within the circuit, and only if it did not wish to appeal. ${ }^{129}$ At this writing it is too soon to tell if this rule will resolve the issue.

In sum, the federal courts ought to do more to bring about changes in Social Security policy so that its procedures will be nore in line with our shared democratic values expressed in the idea of due process. Through their equitable powers, federal judges could inandate incremental procedural reforins. Without the power to mandate the restructuring of this inassive institution, and without the power of the purse, functional limitations and the subtleties of agency nianageinent powerfully restrict what judges can effectively do beyond case-by-case review.

3. The Inadequacy of Conventional Legal Discourse. The necessity of working within the conventions of legal discourse and rhetoric create pragmatic restraints on lawyers and judges; these restraints limit our vision of the transformative possibilities of law. Thus, another part of the problein with Goldberg and other attenipts to use due process to restructure bureaucratic institutions is that such attempts are grounded in conventional legal theories of rights. Much of legal discourse operates under the assumption that there are neutral principles of justice that all people wonld adopt if they thought about the problems of justice rationally, and that legal rules can be identified that necessarily would create a

126. S. 476, 98th Cong., 1st Sess., 129 CoNG. REc. 2201-04 (1983). This provision was amended by the Senate Finance Committee, see S. REP. No. 466, 98th Cong., 2d Sess. 7-10, 21 (1984).

127. WAYS AND MEANS GREEN Book, supra note 13, at 63.

128. Administrative Conference of the United States, Agency Non-acquiescence in Decisions of the Courts of Appeals, 53 Fed. Reg. 12,444 (1988), additional comments solicited, 53 Fed. Reg. 24,331 (1988).

The Administrative Conference, however, ultimately nade no recommendation based on its report. The report, although worded as a general proposal, accepted as legitimate inter-circuit nonacquiescence of the type practiced by the IRS. Its main criticism was of the policy of intra-circuit non-acquiescence of the type that only the SSA practiced. Although no decision was made by the Congress or the Administrative Conferenee, the pressure on the agency was great. Telephone interview with Mary Candace Fowler, Office of the Chairman, Administrative Conference of the United States (Jan. 7, 1990).

129. WAYS AND MEANS GReEN Book, supra note 13, at 63. 
legitimate structure for rational decisionmaking. ${ }^{130}$ These arguments assume that the problems with the legal system derive from failures to grant everyone the rights they would have if people thought about justice neutrally and rationally (like the prohibition of slavery), and from failures to enforce the rights of the oppressed that are already formally recognized (like due process). ${ }^{131}$ Legal reasoning may be a useful tool, but reason in and of itself does not constrain judicial discretion nor does it decide cases. Through legal discourse, the human mind can generate equally plausible rights justifications for a variety of results. ${ }^{132}$ Further, opinions written in the language of rights discourse have an appearance of logical necessity and, therefore, serve to blunt democratic criticism and opposition, rather than highlight the need to make political choices. ${ }^{133}$

When engaging in due process review, courts often write opimions in the language of balancing tests. Balancing tests, like other forms of rights discourse, operate through a rhetorical sleight of hand: Although superficially engaging in value choices, such opinions rarely confront the political nature of the choices necessary to strike the balance. The only method to ascribe weight to the various factors to be balanced is by choosing among competimg social values. The importance of those social values necessarily inust be determined by the deciding judge's notions of justice.

a. Disability and the rhetoric of due process. The Supreine Court's opinion in Mathews v. Eldridge ${ }^{134}$ exemplifies the manipulability of rights discourse. In Eldridge, the Court ${ }^{135}$ reaffirmed Goldberg, but held that the same procedural due process rights required by Goldbergthe right to a face-to-face hearing with the decisionmaker and the right to confront adverse witnesses prior to the termination of benefits-did not

130. See generally B. ACKermaN, Social Justice IN THE Liberal StATE 371-74 (1980); R. DWorkin, A MatTer of Principle 181 (1985); J. RAWLS, A THEORY of Justice 13 (1971).

131. D. KENNEDY, LEgaI EdUCATION AND THE REPRODUCTION OF HIERARChy 22-23 (1983).

132. Id.

133. See generally Cohen, Transcendental Nonsense and the Functional Approach, 35 CoLUM. L. REV. 809 (1935). Cohen writes:

when we recognize that legal rules are simply formulae describing uniformities of judicial decisions, that decisions themselves are not products of logical parthenogenesis born of pre-existing legal principles but are social events with social causes and consequences, then we are ready for the serious business of appraising law and legal institutions in terms of some standard of human values.

Id. at 847 .

134. 424 U.S. 319 (1976).

135. Per Justice Powell, joined by Chief Justice Burger and Justices Stewart, White, Blackmim and Rehnquist. 
apply to a virtually indistinguishable set of facts in the Social Security disability benefits context. ${ }^{136}$

The Court and the government (represented by then Solicitor General Robert Bork) conceded that "the interest of an individual in continued receipt of these benefits is a statutorily created 'property' interest protected by the Fifth Amendment," and as such "[p]rocedural due process imposes constraints on governmental decisions which deprive individuals" of these protected property interests. ${ }^{137}$ The Court concluded, however, that the existing procedures "provide all the process that is constitutionally due before a recipient can be deprived of that interest."138 Again utilizing the language of rights discourse, the Court stated that the "fundainental requirement of due process is the opportunity to be heard 'at a meaningful time and in a meaningful inanner." "139 Although the Eldridge inajority shared with the dissent this due process language, the inajority clearly had a different conception of what constitutes "a meaningful time and in a ineaningful manner." Language is, after all, indeterminate: One Justice's "meaningful" is another Justice's "burdensoine and costly." To determine what is "ineaningful" always requires a pohtical choice.

The juxtaposition of the Goldberg and Eldridge opinions demonstrate the inalleability of ostensibly neutral, apolitical balancing tests. The real-world meaning of such tests einerges only after the values are inolded and the facts in question are poured into thein. The test created in Eldridge requires the balancing of three factors: first, the private interest affected; second, the risk of an erroneous deprivation of such interest through the procedures used and the probable value (i.e., marginal efficiency) of any additional or substitute procedural safeguards; and finally, the government's interest. 140

When analyzing the last of these factors-the governinent's interest (identified as the "public interest")- the Eldridge Court only gave significance to the administrative burden and costs associated with requiring a hearing prior to the termination of disability benefits. ${ }^{141}$ Somewhere

136. The facts of the Eldridge case are simple. A few years after Mr. Eldridge was first awarded disability benefits, he received and completed a short questionnaire from the monitoring state agency. On the basis of this questionnaire and reports from his doctor and a so-called "independent" medical consultant-chosen and paid for by the government-the agency decided to cut off Mr. Eldridge's benefits. Mr. Eldridge brought suit alleging that he was entitled to a hearing before losing his sole means of support, relying upon the due process rights that the Court had enunciated in Goldberg v. Kelly in the welfare context. Mathews v. Eldridge, 424 U.S. 319, 319-20 (1976).

137. Id. at 332 .

138. Id. at 332-33.

139. Id. at 333 (quoting Armstrong v. Manzo, 380 U.S. 545, 552 (1965)).

140. Id. at 335; compare Goldberg v. Kelly, 397 U.S. 254, 263-71 (1970).

141. 424 U.S. at $347-48$. 
along the way the Court dropped what the Goldberg Court had found to be "important governmental interests . . . promoted by affording recipients a pre-termination evidentiary hearing. ... [ [because from] its founding the Nation's basic commitment has been to foster the dignity and well-being of all persons ...."142 For the Goldberg Court, that commitment constituted a key ingredient in understanding the government's interest. In contrast, the Eldridge inajority concluded that our interests are significant only in our capacity as taxpayers.

Unable to substantially differentiate the "public interest" factors in Eldridge from the application in Goldberg, the Court looked to the other two factors in an effort to distinguish the two cases. First, the Court asserted-without any significant support froin the record-that "the disabled worker's need is likely to be less than that of a welfare recipient." 143 Hence the Court distinguished the cases; the private interest in Eldridge was argued to be significantly less substantial than the private interest affected in the welfare context of Goldberg, and so was entitled to less procedural protection. The Court arrived at this conclusion in spite of the fact that "because disability benefits were terminated there was a foreclosure upon the Eldridge home and the family's furniture was repossessed, forcing Eldridge, his wife, and their children to sleep in one bed." 144

The Court made a similarly plausible-sounding, but unsupported claim as to the second factor-the risk of an erroneous deprivation of the interest through the procedures used and the probable value of any additional procedural safeguards. Here too, the Court concluded that "[t]he potential value of an evidentiary hearing, or even oral presentation to the decision maker, is substantially less in this context than in Goldberg." 145

The Court "found" that the disability determination is a technical decision, restimg on a medical assessment. In contrast to the welfare entitleinent determination, the majority asserted, the decision to discontinue disability turns not on "issues of witness credibility and veracity," but rather " upon routime, standard, and unbiased medical reports by physician speciahists,' [so] the 'specter of questionable credibility and veracity is not present." "146 The disability determination, however, is not a technical question. Justice Brennan exphicitly recognized this point in his dissent in Richardson v. Wright. ${ }^{147}$ Justice Brennan argued that however

142. Goldberg, 397 U.S. at 264-65.

143. Eldridge, 424 U.S. at 342.

144. Id. at 350 (Brennan, J., dissenting).

145. Id. at 344-45.

146. Id. at 343-44 (quoting Richardson v. Perales, 402 U.S. 389, 404 (1971)).

147. 405 U.S. 208 (1972). 
reliable the evidence upon which a disability decision is based, and however rarely it involves questions of credibility and veracity, it is plain that, "as with welfare and old-age determinations, the determination that an individual is or is not 'disabled' will frequently depend upon the resolution of factual issues and the apphication of legal rules to the facts found. It is precisely for that reason that a hearing inust be held."148

Further, in Goldberg, the Court recognized that respect for an individual's sense of dignity, autonomy, and fairness required that people be given the opportunity to present their case, to see the decisionmaker, and to confront adverse witnesses. ${ }^{149}$ In Eldridge, however, the Court did not even address the issues of self-respect and alienation that attend bureaucratic decisions over matters important to an individual's life and dignity. Technical "correctness" does not engender a sense of fairness, and hence does not satisfy due process. Yet technical correctness was how the majority cliose to test the values of alternative procedural safeguards.

The Court's test of due process in Eldridge is wrong on several levels. First, the Court failed to recognize the social interest in having decisions made so as to preserve the claimant's dignity. Second, the disability determination is highly subjective and discretionary. Disability is neither a diaguosis nor directly calculable froin medical reports; rather, it is a bureaucratic-legal assessment. ${ }^{150}$ Finally, many of the negative physician reports come from either doctors chosen and paid by the SSA or from doctors hired by the claimani's former einployer to fight the claimant's Workers' Compensation claim-neitler of which constitute an unbiased source. ${ }^{151}$ As in Eldridge, these doctors' reports may conflict with those of the claimant's treating plysician. Without questioning the integrity of those doctors wlo perform nnmerous contract examinations

148. Id. at 216. Justice Brennan continued:

The premise of the Secretary's entire argument is that disability benefits are discontinued "only on the basis of an objective consideration-that the previous disability has ceasedand that the conclusion rests on reliable information." ... [T] he premise is questionable .... [D]isability determinations require "specialized medical and vocational evaluations" and not simply the acquisition of "medical and other relevant data." In any event, there are three grounds, pertinent here, upon which disability can be found to have ceased. None can fairly be characterized by the term "objective."

Id. at 219 (citations omitted).

149. Goldberg, 397 U.S. at 269 (citations omitted).

150. See supra notes $41-70$ and accompanying text.

151. Although the claimant is permitted to submit reports from her treating doctor, the SSA may choose to beheve whichever doctor it wishes. Treating physician's reports are not controlling. See 20 C.F.R. $\$ 404.1546$ (1989).

As Justice Brennan wrote in Wright, "I see no reason to suppose, nor does the Secretary suggest any, that the 'credibility and veracity' of doctors and employers can never be in issue in a disability case. Indeed, the Secretary's new regulations indicate that they may." 405 U.S. at 219 (citations omitted). 
for the government or with employers' imsurance companies, it is reasonable to suggest that the SSA (and the employer's insurance company) will tend to choose those doctors whose diagnoses will match the determinations of the SSA. ${ }^{152}$

The juxtaposition of Eldridge and Goldberg demonstrates the mamipulability rights discourse. Although the words of due process in the two cases are similar, the inusic of human values sounds different indeed.

b. Conservative rights discourse in procedural due process. Restricting the content of what constitutes an "opportunity to be heard at a meaningful time and in a meaningful manner" is not the only way to dismiss the case of a person complaining of a procedural injustice. After Board of Regents $v$. Roth, a court may hold that a person was deprived of something other than "life, liberty or property." Hence, no process was due. ${ }^{153}$ This rhetorical move is useful because if no process is due, then a court simply may dismiss the case without discovery or argument. Further, it reheves a court of the task of distinguishing essentially similar interests, as the Eldridge Court treated the importance of disability payments to the individual and arbitrarily distinguished those payments from the welfare payments in Goldberg.

In his plurality opinion in Arnett v. Kennedy, ${ }^{154}$ then Justice Rehnquist made the clearest expression of this rhetoric of no "cognizable" interest. According to Justice Rehnquist's jurisprudence of procedural due process for the administrative state, Congress-when it creates a new property right-is entitled to proscribe the procedural means by which that right is to be protected. Thus, the creation of a benefit creates only an expectancy interest; an individual's substantive right only includes the expectancy of those procedural limitations that the legislature attached to it. ${ }^{155}$ As Chief Justice Rehnquist explained in Arnett:

The Court will not pass upon the constitutionality of a statute at the instance of one who has availed himself of its benefits.... [W] here the grant of a substantive right is inextricably intertwined with the limitations on the procedures which are to be einployed in determining that right, a hitigant ... inust take the bitter with the sweet. ${ }^{156}$

152. Indeed, in Richardson v. Perales, 402 U.S. 389 (1971), three of the government-retained doctors who were not subject to cross examination were employed by Mr. Perales' former einployer's Workers' Compensation insurance company to defeat Perales' claim for that adversarially awarded benefit. Id. at 413 .

153. Board of Regents v. Roth, 408 U.S. 564 (1971).

154. 416 U.S. 134 (1973). Justice Rehnquist was writing for himself and Chief Justice Burger and Justice Stewart.

155. Id. at 152-53.

156. Id. at 153-54 (citations omitted). 
Because the "property interest which [Kennedy] had ... was itself conditioned by the procedural limitations which had accompanied the grant of that interest," 157 Kennedy was demied recovery.

Although the words are different, the music of Justice Rehnquist's "bitter-sweet" analysis would sound harmonious to a judge of the rightprivilege distinction era. The "bitter with the sweet" analysis does not manitain that a government job or benefit is inerely a privilege. Rather, such analysis argues that the content of procedural rights is defined solely by what the legislature determined those rights should consist of when it created the benefit. Thus, if a plaintiff cannot show he was vested with a property interest greater than that circumscribed by the procedural restrictions laid upon that interest in its creation, then the planitiff is not entitled to a contextual due process analysis. This is true even though the court inay concede that the administrative decision was mistaken and the loss to the individual is grievous. Anomalously, however, no matter how trivial the loss-in-fact may be, if the hitigant is able to Ineet the "vested property" test, then he will be entitled to due process of law-although the circumstances of that process may be minimal. 158

Although a majority of the Court in Cleveland Board of Education v. Loudermill ${ }^{159}$ rejected Justice Rehnquist's "bitter with the sweet" reasoning, Roth's requirement - that the interest affected by a government action be a cognizable "liberty" or "property" interest under the fifth or fourteenth amendment, rather than a mere expectancy-remains good law. ${ }^{160}$ The opinion by Justice White in Loudermill held that:

[T] he "bitter with the sweet" approach misconceives the constitutional guarantce. ... The point is straightforward: the Due Process Clause provides that certain substantive rights-life, hiberty, and propertycannot be deprived except pursuant to constitutionally adequate procedures. The categories of substance and procedures are distinct. Were the rule otherwise, the Clause would be reduced to a mere tautology. "Property" cannot be defined by the procedures provided for its deprivation any more than can life or hiberty. The right to due process "is conferred, not by legislative grace, but by constitutional guarantee."161

Although Justice White would deny fewer hitigants their day in court than would Justice Rehnquist, the Roth requirement of a "cognizable" interest remains. Moreover, the determination that an individual is entitled to the protections of due process does not answer the question of what process is due. Justice White nay differ from Justice Rehnquist as

157. Id. at 155.

158. Van Alstyne, supra note 75, at 490.

159. 470 U.S. 532 (1985).

160. Id. at 541 (citations omitted).

161. Id. 
to whether the due process right is even an issue in a particular case; nonetheless, he generally would find, with his conservative brethren, that the courts should require no more than what the legislature has deigned to grant. Although procedural due process protections inay always apply to a government deprivation, the content, manner, and timing of those constitutionally mandated protections, Justice White argues, depend upon a complex of social, and ultimately, political factors:

[W] should not hold that procedural due process is so inflexible as to require the Court to hold that the procedural protections [delineated by Congress] are insufficient. . . . Necessarily, to some extent, the Court must share with Congress, $\mathrm{im}$ an area where one is called upon to judge the efficacy of particular procedures, a role in defining constitutional requirements, and Congress explicitly left it to the discretion of the agency as to whether such procedures were required. I would not upset that judgment in this case. ${ }^{162}$

Justice White's position is useful for its recognition of the political nature of constitutional rights adjudication. Yet, because he almost always would assume that legislation defines political correctness and, moreover, because he assumes that in the absence of a clear congressional mandate the Court should not interfere with extant procedures or create new rights, Justice White's jurisprudence is operationally similar to Justice Rehnquist's. To Justice Rehnquist, when Congress creates a new right it also can dehneate its attendant procedures without regard to due process; to Justice White, when Congress delineates the content of a right, it defines the social ineaning of due process. The words are different, but the music is the same. The language of rights discourse gives these opinions the appearance of rational decisionmaking based upon objective value balancing and makes their disagreennents appear technical. In the final analysis, however, it is contested social values that are at stake.

Justice White's rhetorical method seens to be the currently domi- . nant discourse of due process. Justice White's approach, therefore, deserves close scrutiny. Lawyers and judges are as constrained by the conventions of argument as they are by the specific holdings of cases. For an argument to prevail in court, or for a judge to avoid reversal, the reigning conventions of legal rhetorical style are as iniportant as the rules of law themselves.

In a recent case regarding private rights of action against agency officials for alleged due process violations, Schweiker v. Chilicky, ${ }^{163}$ the

162. Amett v. Kennedy, 416 U.S. 134, 202 (1974) (White, J. concurring in part and dissenting in part).

163. 487 U.S. 412 (1988). 
Court, ${ }^{164}$ utilized Justice White's method of reasoning to hold that the existence of statutory remedies against the Umited States-although not providing "complete rehef" is a "special factor" counseling against the application of a Bivens-type constitutional tort remedy against state officials for their willful due process violations. ${ }^{165}$ The case provides a paradigm of the currently dominant due process rhetoric. An examination of the case also demonstrates the manipulability of some methods of legal analysis and argument, and shows us the background assumptions-the politics and values-of some of the current Court's members. In Chilicky, the Court assumed that congressional inaction was not inadvertent and that the design of the disability program suggests that Congress provided what it considered to be an adequate remedy for constitutional violations that occur in the course of the program's administration..$^{166}$

The Chilicky case arose from the Reagan Administration's "meat axe approach" to what it perceived as the problem of Social Security disability fraud. In the "contimumg disability review" (CDR) process, state and federal officials allegedly violated due process rights by judging eligibility in light of impermissible quotas, disregarding dispositive favorable evidencc, selecting biased plysicians, purposely using unpubhished criteria and rules inconsistent with statutory standards, arbitrarily reversing favorable decisions, and failing to impartially review adverse decisions. During the first three years of the Reagan administration, approximately 200,000 recipients lost their benefits, ouly to have them restored on appeal.167 As Justice Brennan noted im his dissent in Chilicky,

Just under half of all initial reviews resulted in the termination of benefits, yet nearly two-thirds of those who appealed regained their benefits. Typically, appeals took anywhere from 9 to 18 inonths to process, during which time beneficiaries often lacked sufficient income to purchase necessities and also lost their eligibility for medical coverage. ${ }^{168}$

Congress responded to the disability program crisis with the Social Security Disability Benefits Reform Act of $1984^{169}$. The Act provides a statutory standard to govern disability review. In addition to establishing substantive eligibility criteria and directing the SSA to revise its criteria, Congress enacted several procedural reforms to protect recipients

164. Per Justice O'Connor, joined by Chief Justice Rehnquist, and Justices White, Scalia, and Kennedy.

165. See Bivens v. Six Unknown Named Agents of Federal Bureau of Narcotics, 403 U.S. 388 (1971) (establishing that the victims of a constitutional violation by a federal agent have a right to sue the responsible official personally, for damages resulting froin the constitutional violation).

166. 487 U.S. at $415-16$.

167. Id. at 430 (Brennan, J., dissenting).

168. Id. at $432-33$ (Brennan, J., dissenting) (citations omitted).

169. Pub. L. No. 98-460, 98 Stat. 1794 (1984) (codified in seattered sections of 42 U.S.C.). 
from future erroneous deprivations and to ensure that the review process itself would operate in a fairer and more humane manner. The inost significant provision allowed recipients to elect to continue to receive benefit payments-subject to possible recoupment-through appeal to an ALJ. ${ }^{170}$

The plaintiffs in Chilicky had their benefits terminated improperlyonly to later have them restored. They filed a Bivens suit against a state and two federal officials, seeking money damages for consequential injuries and emotional distress, further conduct that allegedly violated their due process rights. ${ }^{171}$ The Chilicky Court held that because Congress, when enacting the 1984 Reform Act, failed to include a money damages remedy against the responsible officials whose unconstitutional conduct caused the wrongful demal of benefits, a monetary remedy was unavailable. The majority held that Congress is presumed to have balanced governmental efficiency and individual rights in an acceptable manner. ${ }^{172}$ Since Congress examined the problems in the administration of the disability program, the Court found that Congress was unwilling to provide compensation for consequential damages. ${ }^{173}$

Justice Brennan's dissent, which was joined by Justices Marshall and Blackmun, did not take issue with the method of jurisprudential reasoning utilized by the majority, but rather argued that the majority misperceived congressional intent.

I agree that in appropriate circumstances we should defer to a congressional decision to substitute alternative rehef for a judicially created remedy. Neither the design of Title II's administrative review process, however, nor the debate surrounding its reform contain any suggestion that Congress meant to preclude recognition of a Bivens action for persons whose constitutional rights are violated by those charged with administering the program, or that Congress viewed this process as an adequate substitute remedy for such violations. ... I I find it inconceivable that Congress meant by mere silence to bar all redress for such injuries. ${ }^{174}$

The Chilicky opinions provide us with a glimpse into the values and visions of the justices. ${ }^{175}$ But the reigning conventions of legal argument

170. 487 U.S. at 424,435 (Brennan, J., dissenting) (citation omitted).

171. Id. at 412-13; see also supra note 165.

172. 487 U.S. at 423.

173. Id. at 426.

174. Id. at 431-32 (Brennan, J., dissenting).

175. Although liberals may decry the result reached by the majority in Chilicky, they might well agree with its reasoning in a variety of contexts, the inost obvious example being regulatory taking cases. Indeed, the statutory insulation of agencies from judicial rcview was part of the New Deal's answer to judicial intermeddling in progressive programs and marked the formation of the modern bureaucratic state. See, eg., Frankfurter, Labor Injunctions and Federal Legislation, 42 HARv. L. REv. 766, 772-77 (1929) (arguing that the power of federal courts to issue injunctions in labor 
required that the case be argued on the technical issue of the meaning of silence: Does it demand redress or inaction? Either way, congressional silence is fraught with meaning: The world view of the judge inevitably will serve to fill the blanks. These views should be inade explicit. Thus, along with other political actors, judges too should add their voices to the public debate.

c. The limitations of conventional due process rhetoric for the administrative state. Neither recognition of the politically contextual nature of determining what constitutes a fair procedure-and hence what process is due-nor an appeal to an abstract theory of rights, can inandate particular results. The words of either mode of analysis are rhetorical abstractions, only made real when a specific case is decided by a specific judge. Nevertheless, as a practical matter judges inust show deference to congressional mandates. A politicized citizenry can inake its deinands known to Congress. Congress can then inake the mandates of fair procedures more clear, so that even the recalcitrant judge or administrator cannot easily countermand the political will. The proper role for a judge is neither to meddle with the dictates of Congress nor to engage in craven apologetics for the unfair. However, judges can and should play an important role in the politicalization process. In the absence of a politicized citizenry, an appeal to rights will always be broadly manipulatable and indeterminate.

Although manipulable, rights discourse is of limited value as a transformative tool. Rights are by their nature "formal"- that is, they secure legal protection for as well as froin arbitrariness. ${ }^{176}$ Although the appeal made by the more liberal members of the Court to rights and our sense of fairness is more moving than the harsh reasoning of the Court's

disputes should be limited by congressional legislation). The Administrative Procedure Act, Pub. L. No. 79-404, 60 Stat. 237 (1946) (codified as amended at scattered sections of 5 U.S.C.), greatly limits the scope of review that courts may have over administrative agencies, and generally requires that courts show great deference to agency fact-findings. 5 U.S.C. $\$ 706$ (1988). Modern demands for judicial deference to administrative procedures began with liberals and Legal Realists opposed to the active and independent due process jurisprudence of the Lochner era. See, e.g., F. FRANKFURTER, The Red Terror of Judicial Reform, in LAW AND PoLiTIcs 16 (1962) (originally published in 1925) (" $[N]$ o nine men are wise enough and good enough to be entrusted with the power which the unlimited provisions of the due process clauses confer. . . . The due process clauses ought to go.").

176. See D. KenNeDY, supra note 131, at 23. The tendency of liberal thinkers to envision due process rights in terms of formal court procedures is a trap. Such discourse could be used to destroy benign but unconventionally administered programs. In other words, a program may not comport with formal "due process" methods but nevertheless may be politically and socially acceptable, i.e., fair. Moreover, judges, recognizing their operational inability to coherently address procedural due process in the context of the need for mass justice in bureaucratic adjudication, but unwilling to abandon the rhetoric of rights, write opinions full of magic words, sound and fury, that only serve to put a veneer of rectitude upon the alienating and the unfair. 
conservatives, we are, nonetheless, still left with the question of what process is due. What comports with "fundamental fairness" is at best a fuzzy and culturally contingent concept. The magic words of procedural due process tests do not lend themselves to objective testing. As the Court has stated, "We have repeatedly observed that due process requires that a hearing be held 'at a ineaningful time and im a meaningful manner.'"177 However, just what is "meaningful" and what weights should be given to individual and governmental interests in a balancing test are not self-defining.

Value choices are the only means by which we can ascribe weights to the various factors to be balanced. These factors involve the subjective, culturally contingent, cognitive and emotional, ideological and pohtical outlook of the deciding judge. Justice Marshall has argued both that "it remains for us to give content to that general principle [of a meaningful time and in a meaningful manner] by balancing the Government's asserted interests against those of the [affected person]"178 and that the government's interest in efficient procedures "cannot outweigh the constitutional right. Procedural due process is not intended to promote efficiency or accommodate all possible interests: It is intended to protect the particular interests of the person whose [liberty or property is] about to be taken." 179 But if due process depends on balancing social interests and individual interests, then efficiency must be taken into account. Given the needs of mass justice, efficiency is an important social interest. Justice Marshall's rhetoric, although appealing to those who hold individual rights dear and are fearful of bureaucratic overreaching, seeins ill-suited to the requirements of the modern adimnistrative state.

In the context of the administration of disability benefits, securing to claimants the full measure of their formal, legal, procedural due process rights wonld be disastrous for them. Justice Douglas, in his dissent in Richardson v. Perales, argued that due process required that no doctor's reports conld be entered into the record unless tested by cross examination. ${ }^{180} \mathrm{Few}$ doctors, however, would examine disabled patients without charging exorbitant rates if such examinations carried with thein the requirement that the doctor take time off work to testify. It is easy to see that if all 1.2 million disability claimants ${ }^{181}$ were afforded a full adversarial proceeding under the Federal Rnles of Evidence, with a jury as

177. Arnett v. Kennedy, 416 U.S. 134, 212 (1974) (Marshall, J., dissenting) (quoting Armstrong v. Manzo, 380 U.S. 545, 552 (1965)).

178. Id. (Marshall, J., dissenting) (citing Goldberg v. Kelly, 397 U.S. 254 (1970)).

179. Id. at 223 (Marshall, J., dissenting) (quoting Fuentes v. Shevin, 407 U.S. 67, 90 n.22 (1972) (citations omitted)).

180. 402 U.S. 389, 413 (1971) (Douglas, J., dissenting).

181. SSA 1989 ANNUAL REPORT, supra note 12, at 29. 
trier of fact, then the system would rather quickly collapse. As it is, Social Security cases over the last six years have constituted between $4.4 \%$ and $11.5 \%$ of all litigation in the federal district courts. ${ }^{182}$

Although critics may prefer balancing tests or other forms of rights discourse on procedural due process to Justice Rehnquist's admonishment that a litigant must "take the bitter with the sweet," 183 such discourse is limited in its ability to address flaws in the underlying substantive policy. Moreover, this discourse is highly manipulable, with the potential to destroy fairly but unconventionally administered programs. Opinions written in the rhetoric of rights discourse are full of impressive sounding inagic words that often do little more than put a stamp of approval upon the alienating and unfair.

\section{B. Ideological Restraints}

As we have seen, substantial structural and pragmatic linitations restrain judges from directly imtervening to change the nature of a flawed institution. Judges, however, can play a potentially more significant role than policy reform. Enormous potential for contributing to our society's political dialogue resides within the judicial branch. Judges could respect both the pragmatic and structural limitations on the exercise of their power, while contributing to the articulation and development of constitutional and social values. I do not mean that judges should act as social planners, issuing orders and injunctions based on highly contested legal bases. Rather, judges should articulate their social vision and specific policy suggestions as to how our society might better approach constitutional values. The difference is that $m$ the latter case, judges use the bench as a bully pulpit; whereas in the former, judges abuse their power to bully from the safety of the pulpit.

Legal discourse in America today is a world of its own; its language and methods of reasoning are maccessible and inystical to the average person. The average American perceives legal discourse as obfuscation - "mumbo jumbo"- and views lawyers and judges with suspicion, if not outright hostility. ${ }^{184}$ Modern American legal culture, with its jargon

182. This figure is derived from 1989 Administrative OfFice ANNUAL Report, supra note 16, at 7 (Table 3).

183. Arnett v. Kennedy, 416 U.S. 134, 154 (1974).

184. Gallup Report: Political, Social and Economic Trends (Report No. 279, 1988). Only 3\% of the American people rate the honesty and ethical standards of lawyers as very high; $33 \%$ rated lawyers as low or very low. Id. at 18. Although they did rate above car salesmen, lawyers rated below senators, bankers, police officers, and funeral directors. Id. at 3 .

A Harris Poll released May 8, 1988 had the following headline: "Confidence In Institutions Down, Led By Sharp Decline In Trust In White House." The public confidence in the management of law firms is half of what it was in 1973. Id. at 1. 
and arcane reasoning, serves much the same function as the Church in the Middle Ages: It legitimates social structures by claiming that authoritative texts and methods of interpretation mandate them, in ways that most people cannot comprehend. ${ }^{185}$ This is not to say that lawyers and judges are disingenuous: Like the priests of a millennium ago, most jurists no doubt beheve in the system's basic legitimacy and believe that their practice's methods of reasoming reach socially positive results. If we are to have a "government of the people, by the people, for the people," 186 however, we cannot invest great powers in a discourse and practice that is out of step with the way most of the people understand the world-no matter how well intentioned its practitioners may be. That same skeptical eye that we turn upon the authoritative interpreters of that bygone era, we must have the courage to turn upon ourselves.

An organization of federal district and circuit court judges dedicated to making the law generally accessible and understandable, and to articulating how institutions and policy could be transformed to make them more consistent with the goals of the Constitution, could be a powerful force in the transformation of society and law. As it stands now, if a hundred judges behieve the Social Security Administration's procedures violate a democratic conception of due process, then those judges may help the hitigants who come before them, but they may have no wider inpact. If those same one hundred judges formulated an alternative institution to the SSA, petitioned the Congress and presented their ideas to the American people via the press and the media, then they would be a powerful force for social change-even if their judicial exercises of power were restrained. Judges should stop hiding behind suclr "doctrimes" as "the court speaks through its opimion" 187 and have the courage to justify

185. Alexis De Tocqueville observed of the lawyer's art:

[N]othing ... can be more obscure and strange to the uninitiated than a legislation founded upon precedents. The absolute need for legal aid that is felt in ... the United States and the high opinion that is entertained of the ability of the legal profession, tend to separate it more and more from the people and to erect it into a distinct class.... [The] American lawyer reseinbles the hieropliants of Egypt, for like thein he is the sole interpreter of an occult sciencc.

1 A. DE TOCQUeVIlle, Democracy IN AMERiCa 277 (A. Knopf ed. 1946).

186. A. Lincoln, Gettysburg Address (Nov. 19, 1863), reprinted in 2 ABRAHAM LINCOLN: SPEECHES AND WRITINGS 1859-1865, at 536 (D. Felirenbacher ed. 1989).

187. During the Founders' generation appellate opinions, including those of the Supreme Court, were delivered seriatim. ZoBell, Division of Opinion in the Supreme Court: A History of Judicial Disintegration, 44 CORNELl L.Q. 186, 192 (1959). Each judge would express his individual view; thus there was less pretence that an objectively correct interpretation, embodied in the "opinion of the court," existed. This system also gave less precedential effect to judicial dicta: Only the result was the opinion of the court. When John Marshall initiated the practice of giving the "opimion of the court," Jefferson was appalled by the Court's show of unanimity. Jefferson believed that this was a power grab on the part of the Court, creating the impression that the law was something other than a form of political exercise and discourse, and he called its now non-individuated product, "an opin- 
their actions to the American people. If judges saw themselves as articulators of a democratic social vision, rather than as technicians, then the promise of a democratic society would be better fulfilled.

Some may argue that such judicial actions deviate from the proper role of the judiciary. Certainly this type of activism by federal judges would break with present practice. Yet, although the structure of the Constitution does seem to suggest separation of powers and judicial restraint $\mathrm{m}$ the exercise of power, there is nothing in the Constitution that indicates that judges should not articulate their views. Indeed, a judicial role that fosters common pohtical discourse may well be consistent with the intent of the Framers.

Many in the legal community and in the judiciary-whether "liberal" or "conservative"-argue that judges are, or should be, apolitical, neutral appliers of the law, even in constitutional cases that turn on the derivation of fundamental principles of the society. ${ }^{188}$ Yet, under our systein, which invests such great discretionary powers in judges, little could be inore political than the admmistration of justice. From an anthropological and historical viewpoint, it seems puzzling that one stirs controversy by observing that American law is politics.

The historical record does not provide much guidance as to the precise role that judges should play in our society. In our tripartite system of government, the very structure of government mandated by the Constitution botli creates and limits arenas of power. The idea that the judiciary should not mtrude on the turf of the legislature and the executive is

ion ... huddled up in a conclave, perhaps by a majority of one, delivered as if unanimous." Letter from Thomas Jefferson to Thomas Ritchie (Dec. 25, 1820), reprinted in THE WORKS of THOMAS JEFFERSON 175 (Memorial ed. 1905).

188. See, e.g., R. Berger, Government by Judiciary: THe Transformation of the FOURTEENTH AMENDMENT 117-33 (1977) (the criterion of constitutionality is not whether we beheve the law to be for the public good; the only questions for the court are technical); R. BORK, THE TEMPTING OF AMERICA 2 (1990) ("A judge who announces a decision must be able to demonstrate that he began from recognized legal principles and reasoned in an intellectually coherent and politically neutral way to his result."); Carrington, Of Law and the River, 34 J. LEGAL EDUc. 226 (1984) ("[L]awyers like pilots must be always distrustful of themselves, on guard against mistaling their own political or social preferences for those of the law."); E. Meese, Speech of the Attorney General Before the American Bar Association, Washington, D.C. (July 9, 1985), reprinted in THE GREAT DEBATE: INTERPRETING OUR WRITTEN CONSTITUTION 9 (1986) (criticizing Supreme Court opinions as based on policy choices, rather than on technically determinable mandates of the Constitution).

Many in the academy would argue that Legal Realism of the 1920 s and 1930s pushed such notions to the fringes of American legal thought. Within the legal academy, Realism did fundamentally alter conceptions of legal reasoning and of the relationship between law and society. Nevertheless, as the above citations show, formalism has reemerged as the dominant conservative legal ideology. For a thorough explanation of the legacy of Legal Realism, see Singer, Legal Realism Now, 76 CALIF. L. Rev. 465 (1988). 
not without historical and political justification. ${ }^{189}$ The "founding fathers" of botli the Constitution and of the Civil War amendments saw no contradiction in recognizing that certain activities could be unconstitutional, yet beyond the ability of federal courts to rectify. ${ }^{190}$ On the other hand, the Framers also recognized that judges had an important role to play in the formation of policy and common political discourse. ${ }^{191}$

189. However, the Constitution never uses the phrase "separation of powers." Indeed, much historical evidence demonstrates that the Framers of the Constitution adopted a subtle and pragmatic approach to the issue. Bloch, The Early Role of the Attomey General in Our Constitutional Scheme: In the Beginning There Was Pragmatism. 1989 DuKE L.J. 561, 563, 645. It is interesting to note that in 1789 there was a failed attempt to add an explicit "separation of powers" provision. Responding to those concerned with the lack of a separation of powers provision in the Constitution, Madison proposed a new article VII to precede the existing article VII:

The powers delegated by this constitution, are appropriated to the departments to which they are respectively distributed: so that the legislative department shall never exercise the powers vested in the executive or judicial; nor the executive exercise the powers vested in the legislative or judicial; nor the judicial exercise the powers vested in the legislative or executive departments.

12 The PAPERS OF JAMES MAdison 202 (1979). Although the House agreed to this amendment, it was rejected by the Senate. 2 B. SchwarTz, THE BILl of RightS: A DocumentaRY History 1123,1150 (1971).

To be sure the political philosopliy of the 18th century that informed the Framers views was concerned with separation of powers. See J. LOCKE, AN ESSAY CONCERnING THE True OrIGINAL, EXTent, aNd ENd of Civil Government (The Second Treatise) § 91 (1714), in J. LOCKE, TWO TREATISES OF GOVERNMENT (Cambridge ed. 1969); see also C. DE MONTESQUIEU, THE SPIRIT of LAws Book XI, at 149-82 (De l'Esprit des lois 1748) (T. Nugent trans. 1949).

Some today would argue that the separation between branches must be hermetic. See, e.g., Morrison v. Olson, 487 U.S. 654, 709 (1988) (Scalia, J., dissenting) ("It is not for us to determine ... low much of the purely executive powers of government must be within the full control of the President. The Constitution prescribes that they all are."). This view is ahistorical, see Blocl,, supra, and has not been adopted by even most conservative judges. See, e.g., Morrison, 487 U.S. at 690-93 (Chief Justice Rehnquist, writing for all the Court except Justice Scalia, arguing that separation of powers is a flexible concept).

190. Article III vests in the judiciary the jurisdiction over all "cases" and "controversies" arising under the laws, treaties, and Constitution of the United States. U.S. CoNST. art. III, § 2. This grant of power has long been interpreted negatively to limit the ability of individuals to bring suit for the purpose of challenging the constitutionality of the laws and policies of government when they do not have a "personal" stake in the outcome of the litigation. The requirements of standing have been a source of controversy in American constitutional law. See, e.g., Allen v. Wright, 468 U.S. 737 (1984) (denying standing to parents of African American public school children to challenge IRS grant of tax exempt status to discriminatory private schools; discrimination insufficiently connected to IRS incentives to permit standing); Schlesinger v. Reservists Comm. to Stop the War, 418 U.S. 208 (1974) (no one lias standing to cliallenge Members of Congress who violate the incompatibility clause, art. I, $\S 6$, cl. 2, by loolding coinmissions in the Armed Forces Reserve); Frothingham v. Mellon, 262 U.S. 447 (1923) (one cannot aehieve standing to challenge laws by virtue of being a federal taxpayer). See generally P. Low \& J. JefFries, FEDERAL CourTS AND THE LAW OF FEDERAL-STATE RELATIONS 13-66 (1987).

191. Wheeler, Extrajudicial Activities of the Early Supreme Court, 1973 SUP. CT. REv. 128. In 18th century England it was common for judges to advise members of the executive and legislative branches; English norms for judicial conduct actually supported obligatory extrajudicial service. The Founders were, of course, heavily influenced by English norms, and nothing in the Constitution or The Federalist Papers suggests a rejection of the English model. Id. at 145. 
Throughout American history, judges have acted in overtly political roles. During the early national period, Supreme Court Justice Samuel Chase, for example, actively campaigned for President John Adams while on the Court. ${ }^{192}$ John Jay served as envoy to resolve the continuing British-American dispute at the same time that he also served as Chief Justice. ${ }^{193}$ John Marshall also served as Secretary of State during his tenure on the bench. ${ }^{194}$ While President, George Washington freely consulted with sitting Justices of the Supreme Court, treating them as he did his other inforinal advisors. ${ }^{195}$ Although not entirely without controversy at the time, ${ }^{196}$ these examples show that the Framers expected federal judges to be engaged in the formulation and implementation of policy.

In the formative years of both the Constitution and the fourteenth amendment, as well as throughout most of our history, a judge's politics have been a key determinant in his appointment. The Constitution contemplates no role for "apolitical" bodies like the American Bar Association review committee. Instead, article II plainly states that the President "shall have Power, by and with the Advice and Consent of the Senate, ... shall appoint ... Judges of the supreme Court" and the other federal courts. ${ }^{197}$

George Washington and John Adams openly declared their intention to staff the federal bench only witl men whom they believed philosophically compatible. ${ }^{198}$ Thomas Jefferson took office determined to replace the conservative Federalist judiciary that had upheld such partisan and (later considered to be) unconstitutional laws as the Alien and Sedition Acts. He inade it clear that ouly outspoken Democratic-Repubhicans would be considered for appointment to the federal bench. ${ }^{199}$ Abraham Limcoln appoimted only those whose views on the important political issues of slavery and the war were in no way suspect and, in 1863, convinced the Republican-controlled Congress to create a tenth Supreme Court seat for him to fill. ${ }^{200}$

192. A. Kelly, W. Harberson \& H. Belz, The American Constitution: ItS ORioins AND DEVELOPMENT 174 (6th ed. 1983).

193. McKay, The Judiciary and Non-Judicial Activities, 35 LAW \& Contemp. Probs., Winter 1970, at $9,27$.

194. Id. at 28.

195. B. MURPhy, The BRANDEIS/FranKfuRter CONNECTION 347 (1982).

196. Id. at 348.

197. U.S. CONST. art. II, § 2, cl. 2.

198. H. Abraham, Justices and Presidents: A Political History of Appointments to THE SUPREME COURT 64-72 (1974).

199. Id. at 76.

200. Id. at 107-14. 
The historical record also belies the position of those who argue that the Senate's advice and consent to nominations should be largely a technical matter. ${ }^{201}$ The Senate has rejected roughly one out of five candidates formally presented for confirmation; and during the nineteenth century, one out of three nominees was rejected.202 Most of these rejections, particularly in the nineteenth century, were for purely political reasons. ${ }^{203}$ A nuniber of candidates have been rejected because of Senate opposition to the nominating President. ${ }^{204}$ Senators should stop apologizing for rejecting a nominee because of his politics. It is entirely appropriate that the "advice and consent" process be an arena in which a potential judge or justice's social views are put to the political test.

In 1835, Alexis de Tocqueville observed that "[s]carcely any pohtical question arises in the United States that is not resolved, sooner or later, into a judicial question."205 At various points in American history the link between legal and political questions has been generally recognized. These occasions have not been-as the current cominon wisdoin might have it-exceptional. Rather, these have been occasions on which the law-politics distinction has been rendered transparent by the nature of sharply contested politics played out in the courts. Questions of who interprets the Constitution, and what is a legitimate exercise of judicial power, are but proxies for the real political questions of American history. ${ }^{206}$

201. See, e.g., R. BoRK, supra note 188, at 271-355 ("[A]pproach[es] to judging" are legitimate questions of a nominee, as distinguished from questions of doctrine, which are not. It is "inconsistent with the American constitutional design when the Senate" attempts to imfluence the substance of constitutional law through the nomination process.). Id. at 346-47.

202. H. ABRAHAM, supra note 198 , at 8 .

203. Id. at 8-33. Bork claims that in his rejection "we witnessed the first all-out national political campaign with respect to a judicial nominee in our country's history." $R$. BoRK, supra note 188, at 3. Although the nature of campaigns and the use of the media is today quite different than they were in the nineteenth century, his characterization is maccurate. See H. ABRAHAM, supra note 198, at 8-33.

204. H. ABRAham, supra note 198, at 8. During the time of the fornation of the fourteenth amendment, Senate hostility toward Andrew Johnson prevented him from flling a Supreme Court vacancy; Congress even abolished the vacancy to ensure Johnson's impotence. Id. at 32-33.

205. A. DE TocQueville, supra note 185 , at 98 . De Tocqueville also observed that while the magistrates seem to interfere in public affairs only by chance, it is "a chance that recurs every day." Id. at 98 .

206. For a discussion of the Supreme Court as the nation's political philosopher (or "ideologue of American democracy'), see Cover, The Left, the Right, and the First Amendment: 1918-1928, 40 MD. L. REV. 349, 349-50 (1981).

Several early struggles in the controversy over who makes the final interpretation of law involved President Andrew Jackson. During Jackson's tern, civil war almost broke out when the state legislature of South Carolina demanded the right to authoritatively interpret federal law. The hermeneutic disagreement, known as the "nullification" controversy, was settled by a political compromise on the issue of protective tariffs and the threat of force of federal arms. A. SCHLESSINGER, THE AGE OF JACKSON 95-96 (1945). Jackson argued that the Second Bank of the United States was 
The Lincoln-Douglas debates over Dred Scott v. Sandford 207 illustrate that constitutional interpretation and the proper role of the courts was a proxy for the real issues central to pohtical meaning in the crucible of American pohtics during the era leading to the Civil War. ${ }^{208}$ In Lincoln's jurisprudence, judges inust understand that their constitutional interpretations are limited to the parties of the case in front of them, and that judicial interpretations are not supreme to executive and legislative constitutional interpretation. 209 However, we can only wonder if Lincoln's "jurisprudential" arguments would have been the saine if the Court had found that the Missouri Compromise was a legitimate exercise of legislative power and, in so holding, had hinted in dicta that abohition of slavery without compensation to slave owners wonld not violate the takings clause. Many arguments were posited regarding the nature and exercise of judicial power and interpretation in that period; one wonders if, in fact, the real issue was not the politics of judging, but the politics of the judges. 210

unconstitutional, despite a Supreme Court opinion finding it legitimate. In his niessage accompanying his veto of the renewal of the charter of the Bank, whose constitutionality had been upheld by John Marshall in McCulloch v. Maryland, 17 U.S. (4 Wheat.) 316 (1819), Jackson limited the "authority" of Supreme Court opinions to "such influence as the force of their reasoning may deserve." Andrew Jackson, Veto Message, July 10, 1832, in 2 Messages AND PAPERs of THE Presidents 582 (J. Richardson ed. 1896), reprinted in S. LEVINSON, CONSTITUTIONAL FAITH 38 (1988). Jackson transferred federal assets froin the Bank and it collapsed. A. SCHLESSINGER, supra, at 97-98, 264. After the Court decided a land case in favor of an Indian tribe, Jackson is said to have remarked: "John Marshall has made his decision. Now let him enforce itl" The state involved ignored the decision, and Jackson did leave it unenforced. P. BollER, PRESIDENTIAL ANECDOTEs 69 (1981) (citing W. SUMNER, ANDREW JACKSON 227 (1882)).

207. 60 U.S. (19 How.) 393 (1857).

208. See, e.g., A. KELLY, W. HARBERSON \& H. Belz, supra note 192, at 285-87.

209. Id. at 295. Lincohs rejected the legitimacy of the Dred Scott decision and in the debate with Douglas announced that he would not feel bound by it should he be elected to the Senate: "If I were in Congress, and a vote should come up on a question whether slavery should be prohibited in a new territory, in spite of that Dred Scott decision, I would vote that it should." Created EQual? THE Complete Lincoln-Douglas Debates of 1858, at 36 (P. Angle ed. 1958). Moreover, during his first inaugural address, Lincoln declared:

[I]f the policy of the Government upon vital questions affecting the whole people is to be irrevocably fixed by decisions of the Supreme Court, the instant they are unade in ordinary htigation between parties in personal actions the people will have ceased to be their own rulers, having to that extent practically resigned their Government into the hands of that eminent tribunal.

6 MEssages of The PRESIDENTs 9 (Richardson ed. 1897), reprinted in S. LEVINSON, supra note 206 , at 39.

210. In contrast to his statements discussed earlier, see supra note 209, in 1857 Lincoln argued that Supreme Court decisions "on Constitutional questions, when fully settled, should control, not only the particular cases decided, but the general policy of the country, subject to be disturbed only by amendments to the Constitution .... More than this would be revolution." 2 THE COLLECTED WORKS OF ABRAHAM LINCOLN 401 (R. Basler ed. 1953), quoted in Colby, Two Views on the Legitimacy of Non-acquiescence in Judicial Opinions, 61 TuLANE L. REV. 1059, 1070 n.89 (1987). 
In the time of the framing of the Civil War Amendments, judges actively participated $\mathrm{m}$ the political dialogue to help shape public values. Chief Justice Salmon P. Chase assisted in the drafting of the fourteenth amendment. Chase also campaigned actively for the ratification of the fifteenth amendment. ${ }^{211}$ Chase's activities provide a model for the role a judge can play in the popular formulation of democratic values. Moreover, given Chase's role with respect to the Civil War Amendments, the Framers of these Amendinents must have expected judges to play an activist role in shaping popular pohtical consciousness.

In our own era, "respectable" commentators have argned that the great landmark of civil rights cases, Brown v. Board of Education, 212 was a "political" exercise of judicial power and an unprincipled, illegitimate interpretation of the Constitution. ${ }^{213}$ It is unclear why these commentators make the effort to criticize Brown as such, but expend hittle energy in attacking Plessy v. Ferguson, ${ }^{214}$ Civil Rights Cases, ${ }^{215}$ or recent cases that hobble the fight for the civil and human rights of all Americans. ${ }^{216}$

Thus, although the precise political role of judges always has been controversial and unsettled, the currently controlling norms on the political involvement of judges are ahistorical and permiciously repressive. Moreover, the means by which those norms are enforced and transmitted have been perverted. The Constitution specifies the only inetliod by whicl the behavior of judges is to be controlled-the impeachment process. The language of the Constitution suggests that no sanction other than impeachment is permissible. The Constitution recognizes no role for trade associations, such as the American Bar Association, to promulgate a code of "ethics" binding upon the judges.217 Nevertheless, the A.B.A. Code of Judicial Conduct, adopted by the Judicial Conference of

211. B. MURPHY, supra note 195 , at 360 .

212. 349 U.S. 294 (1955).

213. See, e.g., R. BERGER, supra note 188, at 117-33 (arguing that segregation was consistent with the intent of the Framers of the fourteenth amendment); R. BoRx, supra note 188, at 74-84 ("[T]he combined disingenuousness of the Brown opinion and the obvious moral rightness of its result had ... a calamitous effect upon the law."). Id. at 76.

214. 163 U.S. 537 (1896).

215. 109 U.S. 3 (1883).

216. See, e.g., Wards Cove Packing Co., Inc. v. Antonio, 109 S. Ct. 2115 (1989) (raising the evidentiary burden on plaintiffs in disparate impact employment discrimination suits).

217. "The Judges, both of the supreme and inferior Courts, shall hold their Offices during good Behavior, and shall ... receive for their Services a Compensation, which shall not be diminished during their Continuance in Office." U.S. CoNST. art. III, § 1. Unlike the removal of the President, which can only be predicated upon the technically defined erimes of "Treason, Bribery, or other high Crimes and Misdemeanors," Id. art. II, $\S 4$, the Senate, as the body charged with "the sole Power to try all Impeachments," Id. art. I, $\S 3$, cl. 6 , is the sole judge of what constitutes judicial "good behavior." 
the United States in 1973,218 represents an attenipt to confine the political expressions of judges. Canon 5B permits a judge to participate in civic and charitable activities only if such activities "do not reflect adversely upon his impartiality or interfere with the performance of his judicial duties."219 At first, this proscription nay appear reasonable; however, the rule poses a line-drawing problem: Where do a judge's duties end and her first amendnient rights begin? 220

A recent Florida case illustrates the illegitimacy of these professionally controlled norms. In In re Gridley, a case adjudicated under the Code of Judicial Conduct, a state judge was brought up on charges for having written two letters to a local newspaper that, while stating that he would uphold the law as written, discussed Christian forgiveness and capital punishment. ${ }^{221}$ Judge Gridley's attempt to galvanize public opinion on important social values should be pronioted, not chilled. The political process, through impeachment (or m many states, recall) is the only means by which judicial activity should be regulated.

The Judicial Code also forbids judges from accepting appointment to any governmental committee or commission that is "concerned with issues of fact or policy."222 Judicial involvenient in just such activities has been common in American history from the tinie of the Franiers to the present, and has often been of significant beneficial importance. ${ }^{223}$ Justice Robert Jackson's service as the chief American prosecutor at the Nüremberg War Crimes Trials, and Chief Justice Warren's chairmanship of the commission charged with the investigation of the death of President Keimedy, for example, were of great importance to the healing of the Nation at times of crisis. Nevertheless, according to the "profes-

218. AMERican Bar Association, Standing Committee on Ethics and Professional RESPONSIBILITY (1988). The Judicial Conference of the Umited States is the policy-making body of the federal courts by virtue of 28 U.S.C. $\S 331$ (1988).

219. Model Code of Judicial Conduct Canon 5B (1972).

220. Other Western democracies do not question the right of judges to actively engage in even partisan political activities. The Judges Law of the Federal Republic of Germany, for example, requires judges to maintain their independence, but assumes that judges will be politically active. "A judge, whether on or off the bench, has to conduct himself, even when acting politically [when engaged in political actionl, so that confidence in his independence will not be jeopardized." German Judges Law, Deutsches Richtergesetz, BGB1.I \& 39, at 713 (Apr. 19, 1972) (as amended) (translation by Professor Herbert Bernstem, Duke Law School). German judges are indeed active at all levels of that country's politics; all of the major political parties have lawyers groups that include judges sections. Interview with Professor Herbert Bernstein, Duke Law School (Mar. 15, 1990).

221. 417 So. 2d 950 (Fla. 1982). Judge Gridley ultimately was exonerated.

222. Model Code of Judicial Conduct Canon SG (1972); see also S. Lubet, Beyond REPROACH: ETHICAL RESTRICTIONS ON THE EXTRAJUdicial ACTIVITIES Of STATE AND FEDERAL JUDGES 28 (1984).

223. See supra notes 191-200 and accompanying text. 
sional ethicists," such activities, despite their importance and long acceptance, are branded as "unethical."224

Federal judges should reject the imposition of these ahistorical guild-promulgated norms upon their activities, and Congress should reject this imposition upon an area that is solely its prerogative. What constitutes judicial good behavior is a socially determined normative choice. In a democracy such choices should be determined through the poitical process.

Judges should see themselves and be seen by the public for what they inexorably are-political actors. The shield of judicial "neutrality" serves both to obfuscate from the pubhic what judges do, and it allows judges to live in a fantasy world in which they can decide cases without having to fully consider the social ramifications of their actions. ${ }^{225}$

All the current discussion about so-called judicial activism provides another instance of legal thinkers abstracting the stories of human struggle to fit the perspective of their practice. But the social meaning of those abstractions becomes real only when concrete facts are considered and actual cases are decided. If you like existing constitutional doctrine, then you favor stare decisis; if you cannot abide extant constitutional law, then you agree that although stare decisis is important, the Supreme Court has an obligation to "correct mistaken" decisions of constitutional law, because if they do not, no one else can. ${ }^{226}$ Similarly, if you like the acts of Congress, then you are for judicial restraint; if you cannot abide the acts

224. S. LUBET, supra note 222 , at 27-28. In one significant case, a federal judge has challenged such restrictions. Judge Irving Kaufman of the Court of Appeals for the Second Circuit, who has had disputes with the Justice Department over his chairmanship of the President's Commission on Organized Crime, has criticized the use of any means other than impeachment for disciplining judges: "[A]ny simpler process ... . even oue under the control of judges themselves, would eviscerate the independence of the individuals on the bench." Kaufman, Chilling Judicial Independence, 88 YALE L.J. 681, 685 (1979). Judge Kaufman maintains that there are already ample mechanisms for dealing with misconduct-the appointment process, appellate review and peer pressure.

225. See generally J. FRANK, LAW AND THE MODERN MIND (1930). Frank writes:

The judge is trying to decide what is just; his judgment is a "value judgment" and most value judgments rest upon obscure antecedents. We cannot, if we would, get rid of emotions in the field of justice. The best we can hope for is that the emotious of the judge will becoine inore sensitive, inore micely balanced, more subject to his own scrutiny, more capable of detailed articulation.

Id. at 153. Gabel, Founding Father Knows Best, 36 Buffalo L. REv. 227, 229 (1987) (The New Right uses legal formalisun and "the jurisprudence of original intent" to anchor in mass consciousness a new mythic, historical narrative about the origins and uature of "our society" that can then serve as the psycho-political foundation for a passively accepted, conservative legal order.).

226. See Address by the Honorable Antonin Scalia, Duke Law Journal Administrative Law Lecture (Jan. 24, 1989) (Justice Scalia's response to a question from the audience concerning stare decisis) (available froin author). In Webster v. Reproductive Health Servs., 109 S. Ct. 3040 (1989), the normally "conservative" Chief Justice Rehnquist argued that stare decisis "has less power in Constitutional cases." Id. at 3056. See also Frickey, Stare Decisis in Constitutional Cases: Reconsidering National League of Cities, 2 CONST. COMMENTARY 123 (1985) (discussing the fiexibility of the 
of Congress, then you believe that they violate the Constitution-as it is "correctly" interpreted. Many today would maintain, as Justice Roberts did in United States v. Butler, ${ }^{227}$ that there is no contradiction between judicial restraint, and the striking down of an act of Congress:

It is sometimes said that the Court assumes a power to overrule or control the action of the people's representatives. This is a misconception. When an act of Congress is appropriately challenged in the courts as not conforming to the constitutional mandate, the judicial branch of the government has only one duty; to lay the article of the Constitution which is invoked beside the statute which is challenged and to decide whether the latter squares with the former. . . This court neither approves nor condemns any legislative policy. Its dehcate and difficult office is to ascertain and declare whether the legislation is in accordance with, or in contravention of, the provisions of the Constitution; and having done that, its duty ends.228

Many jurists and academics believe that just such a syllogistic process describes low constitutional law ought to be formulated, and that any other formulation is somehow illegitimate. ${ }^{229}$ However, it is clear that froin the Frainers' time to our own, the open-ended nature of constitutional rights has required that judges do more than compare articles of the Constitution with the challenged statute and decide on the basis of objective comparison whether the latter squares with the former. Judges inust strive to articulate the American people's vision of what the Constitution's words mcan in concrete life situations.

\section{CONCLUSION: TOWARD A REALISTIC ThEORY of Judicial Discourse}

In the final analysis, the Social Security disability system's operation violates procedural due process, but this violation occurs im subtle ways that are not ainenable to quick fixes. The problems with the system are pohitical and structural. In its very conception, the Social Security disability system is mcoherent, reflecting the structural contradictions of

doctrine of stare decisis especially in the face of decisions that are "generally" considered to be wrong).

227. 297 U.S. 1 (1936).

228. Id. at 62 .

229. See, e.g., Kay, Adherence to the Original Intentions in Constitutional Adjudication, $82 \mathrm{Nw}$. U.L. REv. 226, 254 (1988) (Constitution provides a determinate decision on the constitutionality for every possible action no matter how different from the things and circumstances the constitutionmakers had in mind); see also R. BERGER, supra note 188, at 117-33, 363-72 (only significant question when reviewing the legality of an exercise of power is whether it is enumerated in the Constitution; if the answer is no, it is unconstitutional); R. BoRK, supra note 188, at 7 ("the orthodoxy of original understanding, and the political neutrality of judging it requires, are the only legitimate inethods of legal reasoning"); E. Meese, supra note 188, at 9 (Supreme Court opinions are only correct when they derive from the technically determinable mandates of the Constitution). 
American society. We want the disabled to have decent medical care, but for complex political reasons Congress chose not to have the government run medical care or even diagnostic services. We require everyone who can work to do so, but we will not ensure that they are able to do so, nor ensure that there is work for them to do. It takes little imagination to see that disability, unemployment, social welfare, job training, health care and rehabilitative medicine, child care, employment services, and regional economic development are all logically linked. The amehioration of any of these problems requires a comprehensive strategy.

We must mend the holes im the social safety net; part of that project is a comprehensive and coordinated approach to the needs of disabled Americans. The disabled need "one-stop shopping"-government centers where they can receive a mix of job referrals and job development, health care, vocational training and rehabilitation, as well as support benefits, tailored to individual needs.

Judges, however, have a limited role to play in creatimg such an institution. As a practical matter, judges do not have the power to recast massive national institutions such as the Social Security Administration; moreover it would not be generally perceived as legitimate and democratic for them to even attempt to overhaul these congressionally created institutions. Judges are, however, uniquely well suited to critique the existing patchworked and unfair system and to lobby for comprehensive changes. Judges do have the power to speak, and further, they have power and ability to ensure that they will be heard.

Yet, it must be intensely frustrating to hold the role of interpreter of constitutional values, but be impotent to ensure that those values are carried into action. 230 The judicial role is fraught with paradox. Public law adjudication often requires that judges evaluate whether the operation of governmental activities are consistent with our constitutional values, but structural and pragmatic constramts limit what they can do to make our institutions hive up to our values. Many judges view themselves as legal technicians, as craftsmen, as "professionals," and thus see no contradictions. Human beings need to believe-and want others to believe-that their decisions are determinate, principled, and correct. Judges do not want to write, "given my background, culture, values and life experiences-as well as a recognition of how bittle change I can really effect

230. De Tocqueville thus expressed the conundrum of judicial power:

Their power is enormous, but it is the power of public opinion. They are all-powerful as long as the people respect the law; but they would be impotent against popular neglect or contempt of the law. The force of public opinion is the most intractable of agents, because its exact limits cannot be defined; and it is not less dangerous to exceed than to remain below the boundary prescribed.

A. DE TOCQUEVILLE, supra note 185 , at 150. 
given the limitations of iny institutional role-this is what I think the American people would agree is fair." Instead, many judges safeguard themselves with their syllogisms, their magic words and incantations, the tests that test only in the abstract, but do not, in fact, guide concrete human affairs. As with all political choices, no mechanical tests can answer legal questions. As Justice Frankfurter explained, when writing on administrative law and its tests: "[J]udges are not automata." He added:

Since the precise way in which courts interfere with agency findings cannot be imprisoned within any form of words, new formulas atteinpting to rephrase the old are not likely to be more helpful than the old. There are no talismanic words that can avoid the process of judgment. The difficulty is that we cannot escape ... the use of undefined defining terms. ${ }^{231}$

Administrative law and the social need for efficient mass justice in the welfare state liave created new cliallenges for the legal system. Acquiescence to the procedures created by Congress or an agency does not further the development of the meaning of fairness or the constitutional values embodied in the due process clauses. On the other hand, the model of due process as traditional adjudication is ill-suited to the needs for mass justice in the context of modern bureaucratic institutions. Judges must have the courage to shed the traditional, formalist abstractions of the Riglit and the Left; they must organize to articulate and demystify the meaning of constitutional values. This Note calls for a new kind of judicial activism, the activism of articulation and dialogue.

Anthony Taibi

231. Universal Camera Corp. v. NLRB, 340 U.S. 474, 489 (1951). 